\title{
EFFECTS OF HOOP REINFORCEMENT IN STEEL AND REINFORCED CONCRETE COMPOSITE SECTIONS
}

\author{
T. Suzuki ${ }^{1}$, K. Takiguchi ${ }^{2}$, T. Ichinose ${ }^{3}$ and T. Okamoto ${ }^{4}$ \\ Presented at the Third South Pacific Regional Conference on \\ Earthquake Engineering Wellington, May 1983.
}

SYNOPSIS

A new version of steel and reinforced concrete (SRC) structural system is proposed. It consists of $\mathrm{H}$-shaped high strength steel, concrete and hoop reinforcement. Longitudinal reinforcement is not used. Experiments were carried out to study the restoring force characteristics of the proposed SRC, with emphasis on the effects of hoop reinforcement. Hoop reinforcement improved the compressive behaviour of the concrete and protected the H-shaped steel from local buckling. The proposed SRC system showed a large energy dissipating capacity as well as a large deformation capacity.

\section{INTRODUCTION}

The steel and reinforced concrete composite (SRC) is one of the commonly used structure systems in Japan. The customary SRC is composed of $H$ or cross-H shaped normal strength steel (S) and reinforced concrete $(\mathrm{R} / \mathrm{C})$ with longitudinal reinforcement. The objective of this study is to develop a new SRC, "H or cross-H shaped high strength steel" - "concrete" - "hoop reinforcement" composite.

One feature of the proposed SRC structural system is the non-usage of longitudinal reinforcement. When the deformed bar is used as the longitudinal reinforcement, the bond between deformed bar and concrete induces the inclined flexural shear cracks which make the concrete less ductile for the compressive straining. The authors intend that the concrete should be liberated from the truss action in the proposed SRC system. The experiment of reinforced concrete beams subjected to antisymmetric bending shear have shown that, when the longitudinal reinforcement of the beam are completely deprived of the bond and are well anchored, the cracks of the beam concentrate at the critical section and only the arch action dominates in the concrete. Such R/C member does not have much hysteretic energy dissipating capacity because the unbonded longitudinal bars do not sustain the compressive stress and are not the source of energy dissipation any more (see appendix). In the case of the SRC member however, the H-shaped steel itself can be the main source of energy dissipation. So the longitudinal reinforcement is abandoned in the proposed SRC; the role of the longitudinal bar is replaced by the larger section of H-shaped steel. The BULLETIN OF THE NEW ZEALAND NATIONAL SOCIETY FOR EARTHOUAKE ENGINEERING, VOL. 17, NO. 3, SEPTEMBER 1984 role of the concrete is limited in the arch action to sustain the diagonal compressive force and the axial force. The non-usage of the longitudinal reinforcement brings about another merit; it shall reduce the congestion of reinforcement which leads to better concrete placing.

Another feature of the proposed SRC structural system is the usage of high strength steel instead of normal strength steel. This might cause the following three problems concerning the deformation capacity of the structure.

- The concrete might not be able to sustain the compressive stress at small ductility factor, because the yield strain of the high strength steel is large.

- Local buckling of the compressive steel flange might occur, because the thickness of the steel plate should be designed thinner than that of normal strength steel.

- The tensile fracture of steel flange at the critical section might be induced by the imperfection of the welding and by the inelastic strain con-

1 Professor, Tokyo Institute of Technology, Tokyo, Japan. Associate Professor, Nagoya Institute of Technology, Nagoya, Japan.

3 Research Associate, Nagoya Institute of Technology, Nagoya, Japan.

4

Graduate student, Tokyo Institute of Technology, Tokyo, Japan. centration; the welding of high 


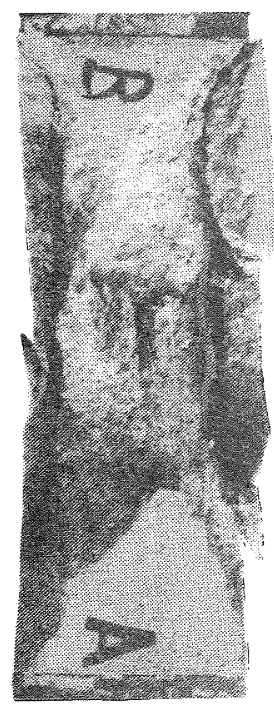

Photo 1 HT80-000-C

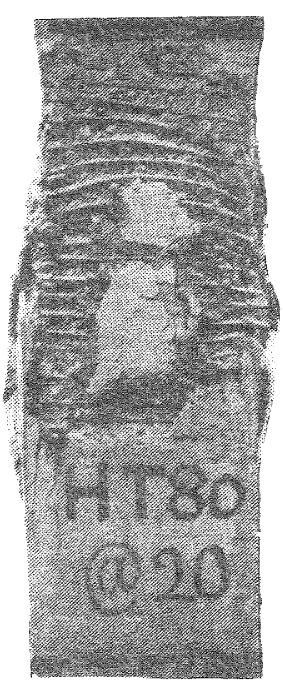

Photo 2

HT 80-020-C

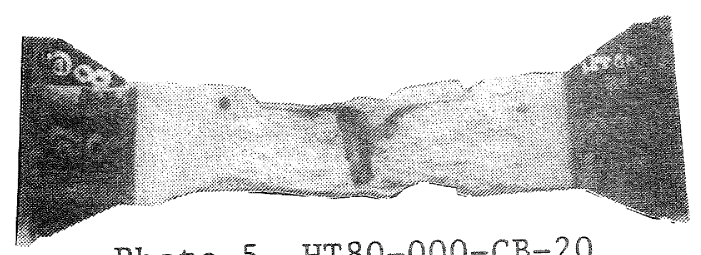

Photo 5 HT 80-000-CB-20

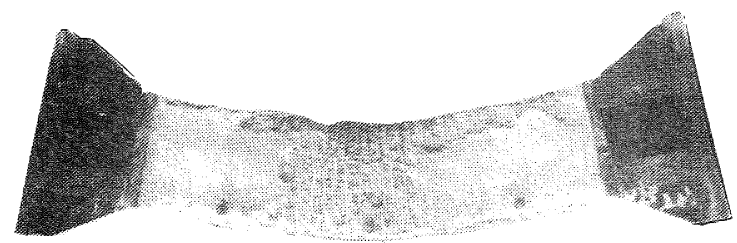

Photo 6 HT 80-020-CB-20

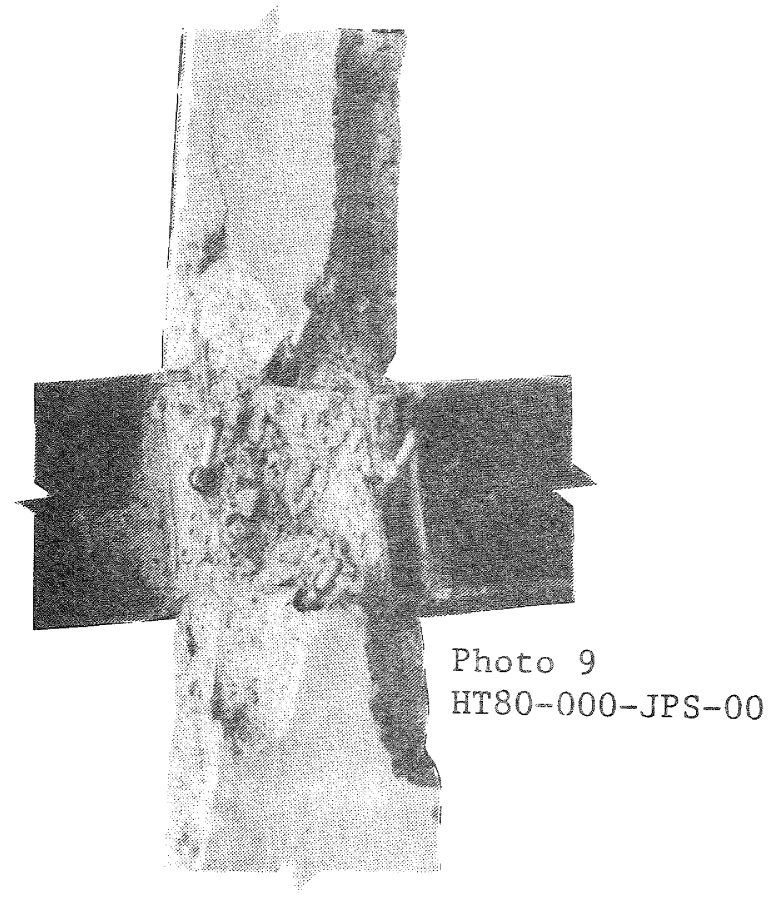

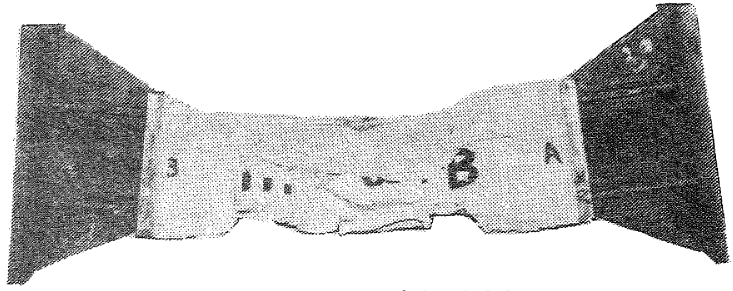

Photo 3 HT80-000-B

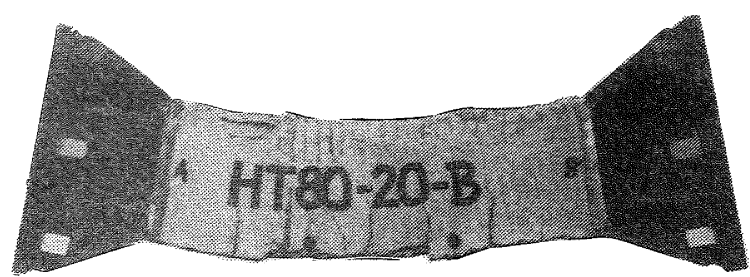

Photo 4 HT 80-020-B

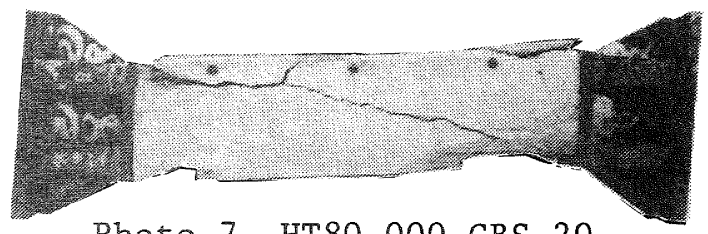

Photo 7 HT 80-000-CBS-20

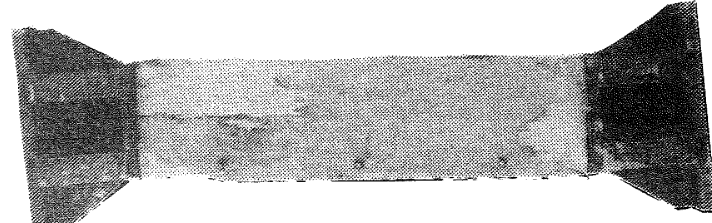

Photo 8 HT 80-020-CBS-20

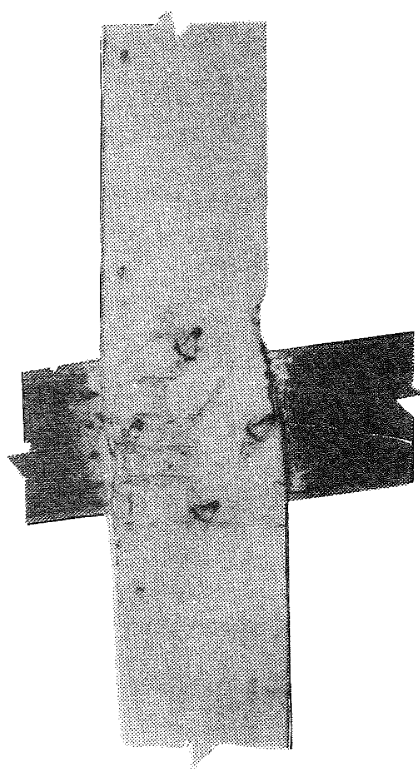

Photo 10

HT80-040-JPS-00 
Table 1 List of Compression Test Specimens

\begin{tabular}{|c|c|c|c|c|}
\hline $\begin{array}{l}\text { Hoop Reinforcements } \\
(\mathrm{mm})\end{array}$ & $-6 \phi-020$ & $6 \phi-(040$ & $6 \phi-100$ & no hoop \\
\hline H $\begin{array}{c}150 \times 100 \times 3.2 \times 4.5 \\
(5 S 41)\end{array}$ & $\begin{array}{l}\text { LH- } 020-C \\
(58)\end{array}$ & $\begin{array}{l}\text { LH-040-C } \\
(59)\end{array}$ & $\begin{array}{l}\frac{L H-100-C}{(58)} \\
(58)\end{array}$ & $\begin{array}{l}\text { LH }-000-C \\
(58)\end{array}$ \\
\hline $\begin{array}{c}\text { H } 150 \times 100 \times 6 \times 9 \\
(5541)\end{array}$ & $\begin{array}{l}\mathrm{RH}-020-\mathrm{C} \\
(227)\end{array}$ & $\begin{array}{l}\text { RH-040-C } \\
(226)\end{array}$ & $\begin{array}{l}\text { RH-100-C } \\
(226)\end{array}$ & $\begin{array}{l}\text { RH-000-C } \\
(227)\end{array}$ \\
\hline $\begin{array}{c}H 150 \times 100 \times 8 \times 8 \\
(H T 60)\end{array}$ & $\begin{array}{l}\text { HT60-020-C } \\
(227)\end{array}$ & $\begin{array}{l}\text { HT60-040-C } \\
(228)\end{array}$ & $\begin{array}{l}\text { HT60-100-C } \\
(228)\end{array}$ & $\begin{array}{l}\text { HT60-000-C } \\
(228)\end{array}$ \\
\hline $\begin{array}{r}\text { H } 150 \times 100 \times 8 \times \\
(H T 80)\end{array}$ & $\begin{array}{l}\text { HT80-020-C } \\
(227)\end{array}$ & $\begin{array}{l}\text { HT } 80-040-\mathrm{C} \\
(227)\end{array}$ & $\begin{array}{l}\text { HT } 80-100-\mathrm{C} \\
(226)\end{array}$ & $\begin{array}{l}\text { HT80-000-C } \\
(226)\end{array}$ \\
\hline $\begin{array}{l}\text { without stee }] \\
{[\text { reinforced }} \\
\text { concrete }]\end{array}$ & $\begin{array}{l}R C-020-C] \\
(100) \\
R(-020-C 2 \\
(110)\end{array}$ & $\begin{array}{l}\text { RC-040-Cl } \\
(103) \\
R C-1040-C 2 \\
(110)\end{array}$ & $\begin{array}{l}\text { RC-100-C1 } \\
(103) \\
\text { RC-100-C2 } \\
(106)\end{array}$ & $\begin{array}{l}\text { RC-000-C1 } \\
(100) \\
\text { RC-000-C2 } \\
(110)\end{array}$ \\
\hline $\begin{array}{l}\text { Nominal Size of } \\
\text { H-shaped Stee) } \\
\text { Section (mm) } \\
\text { (Standardized } \\
\text { Classification } \\
\text { of Steel) }\end{array}$ & \multicolumn{4}{|c|}{$\begin{array}{l}\text { Name of Specimen } \begin{array}{l}\text { Age of the concrete when the specimen } \\
\text { was tested } \\
\text { (days) }\end{array} \\
\text { [Common Items] } \\
\text { Section of Specimen : } 21 \mathrm{~cm} \times 21 \mathrm{~cm} \\
\text { Date of Concrete Placing : October } 6,1980 \\
\text { Maximum Size of Coarse Aggregate : 10 mm }\end{array}$} \\
\hline
\end{tabular}

Table 2 Mechanical Properties of Steel and Reinforcing Bar in Compression Test and Bending Test Specimens

\begin{tabular}{|c|c|c|c|c|c|c|c|}
\hline \multirow{3}{*}{$\begin{array}{l}\text { Standardized Classification } \\
\text { Noninal Thickness or } \\
\text { Diameter }(\mathrm{mm})\end{array}$} & \multicolumn{6}{|c|}{ Steel Plate } & \multirow{3}{*}{$\begin{array}{c}\begin{array}{l}\text { Reinforcing } \\
\text { Bar }\end{array} \\
\text { SR24 } \\
6\end{array}$} \\
\hline & \multicolumn{4}{|c|}{$\$ \$ 41$} & HT60 & HT8O & \\
\hline & 3.2 & 4.5 & 6 & 9 & 8 & 8 & \\
\hline $\begin{array}{l}\text { Actual Thickness or } \\
\text { Diameter }(\mathrm{mm})\end{array}$ & 3.06 & 4.23 & 5.66 & 8.27 & 7.92 & 8.37 & 5.43 \\
\hline Yield Strength (ton $/ \mathrm{cm}^{2}$ ) & 3.18 & 3.21 & 3.90 & 3.41 & 5.89 & 7.99 & 3.41 \\
\hline Tensile Strength $\left(\right.$ ton $\left./ \mathrm{cm}^{2}\right)$ & 4.62 & 4.75 & 5.11 & 4.83 & 6.73 & 8.39 & 4.40 \\
\hline $\begin{array}{l}\text { Strain at the Onset of } \\
\text { Strain Hardening ( })\end{array}$ & 1.5 & 1.4 & 2.5 & 2.4 & 2.2 & $\stackrel{2.0}{\sim 2.4}$ & $\stackrel{0.8}{\sim 1.0}$ \\
\hline Elongation (1) & 38.4 & 39.1 & 23.3 & 27.1 & 29.0 & 23.9 & 28.5 \\
\hline $\begin{array}{l}\text { Dimensions of Test Piece } \\
\text { (31s Z 2201) }\end{array}$ & No. 5 & No. 5 & $\begin{aligned} \text { No. } \\
(B)\end{aligned}$ & $\begin{array}{r}\text { No. } 1 \\
(B)\end{array}$ & No. 5 & No. 5 & No.2 \\
\hline
\end{tabular}

Table 3 Mechanical Properties of Concrete in Compression Test and Bending Test Specimens

\begin{tabular}{|c|c|c|c|c|c|c|c|}
\hline Age (days) & 35 & 71 & 113 & 165 & 249 & 273 & 281 \\
\hline $\begin{array}{l}\text { Compressive Strength } \\
\qquad \mathrm{FC}\left(\mathrm{kg} / \mathrm{cm}^{2}\right)\end{array}$ & 301 & 353 & 348 & 342 & 341 & 335 & 334 \\
\hline $\begin{array}{ll}\text { Splitting Tensile } \\
\text { Strength }\left(\mathrm{kg} / \mathrm{cm}^{2}\right)\end{array}$ & 30.3 & $\cdots$ & 31.8 & ---- & 27.2 & 29.9 & 29.7 \\
\hline $\begin{array}{l}\mathrm{Fc} / 3 \text { Secant Modulus } \\
\left(10^{5} \mathrm{~kg} / \mathrm{cm}^{2}\right)\end{array}$ & 2.3 & $\cdots$ & 2.4 & $\ldots$ & 2.5 & 2.5 & 2.5 \\
\hline $\begin{array}{l}\text { Strain at the } \\
\text { Maximum Stress (\%) }\end{array}$ & $\stackrel{0.23}{\sim 0.28}$ & $\ldots$ & $\stackrel{0.26}{\sim 0.30}$ & $\cdots$ & $\stackrel{0.26}{\sim 0.31}$ & $\begin{array}{l}0.21 \\
\sim 0.26\end{array}$ & $\begin{array}{l}0.21 \\
\sim 0.26\end{array}$ \\
\hline \multicolumn{8}{|c|}{$\begin{array}{l}\text { Diameter and Height of Cylinder : } 10 \mathrm{~cm} \times 20 \mathrm{~cm} \\
\text { Curing : in Air } \\
\text { Maximum Size of Coarse Aggregate : }: 10 \mathrm{~mm} \text { Slamp: } 15 \mathrm{cmi}\end{array}$} \\
\hline
\end{tabular}

Table 4 List of Bending Test Specimens

\begin{tabular}{|c|c|c|c|c|}
\hline $\begin{array}{l}\text { Hoop Reinforcemients } \\
(\mathrm{mm})\end{array}$ & $-64-020$ & $6 \phi-040$ & $6 \phi-\theta 100$ & no hoop \\
\hline $\begin{array}{l}H \quad 150 \times 100 \times 3.2 \times 4.5 \\
(5541)\end{array}$ & $\begin{array}{l}\text { LH- } 020-B \\
(50-51)\end{array}$ & $\begin{array}{l}\text { LH-040-B } \\
(47-49)\end{array}$ & $\begin{array}{l}\text { LH-100-B } \\
(39-42)\end{array}$ & $\begin{array}{l}\text { LH-000-B } \\
(36-38)\end{array}$ \\
\hline 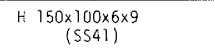 & $\begin{array}{l}\text { RH-020-8 } \\
(254-255)\end{array}$ & $\begin{array}{l}\text { RH-040-B } \\
(246-247)\end{array}$ & $\begin{array}{l}\text { RH-100-B } \\
(249-250)\end{array}$ & $\begin{array}{l}\text { RH-000-B } \\
(252-253)\end{array}$ \\
\hline H $\begin{array}{c}150 \times 100 \times 8 \times 88 \\
(H T 60)\end{array}$ & $\begin{array}{l}\text { HT60-020-B } \\
(268)\end{array}$ & $\begin{array}{l}\text { HT60-040-B } \\
(261-262)\end{array}$ & $\begin{array}{l}\text { HT60-100-8 } \\
(266-267)\end{array}$ & $\begin{array}{l}\text { HT60-000-B } \\
(264)\end{array}$ \\
\hline 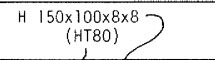 & $\begin{array}{l}\begin{array}{l}\text { HT80-020-B } \\
(277)\end{array} \\
\end{array}$ & $\begin{array}{l}\text { HT } 80-040-B \\
\langle 275-276)\rangle\end{array}$ & $\begin{array}{l}\text { HT80-100-8 } \\
(270-271)\end{array}$ & $\begin{array}{l}\text { HT80-000-B } \\
(273-274)\end{array}$ \\
\hline $\begin{array}{l}\text { Nominal Size of } \\
\text { H-shaped Stee) } \\
\text { Section (mm) } \\
\text { (Standardized } \\
\text { Classification } \\
\text { of Steel) }\end{array}$ & \multicolumn{4}{|c|}{$\begin{array}{l}C_{\text {Nanie of Specimien }} \begin{array}{c}\text { Age of the concrete when the specimen } \\
\text { was tested (days) }\end{array} \\
\text { [Cominion Items] } \\
\text { Section of Specimen : } 21 \mathrm{~cm} \times 21 \mathrm{~cm} \\
\text { Date of Concrete Placing: October } 6,1980 \\
\text { Maxinum Size of Coarse Aggregate: } 10 \mathrm{~mm}\end{array}$} \\
\hline
\end{tabular}




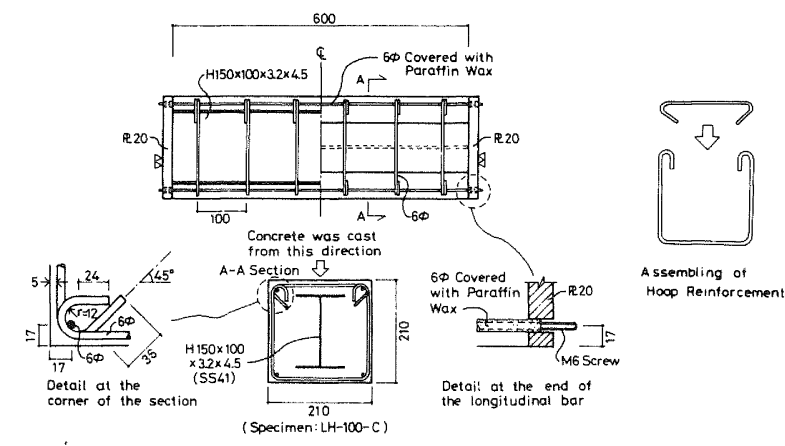

Fig 1 An Example of Compression Test Specimen

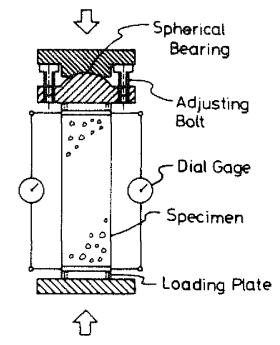

Fig 2 Loading and Measuring System of Compression Test

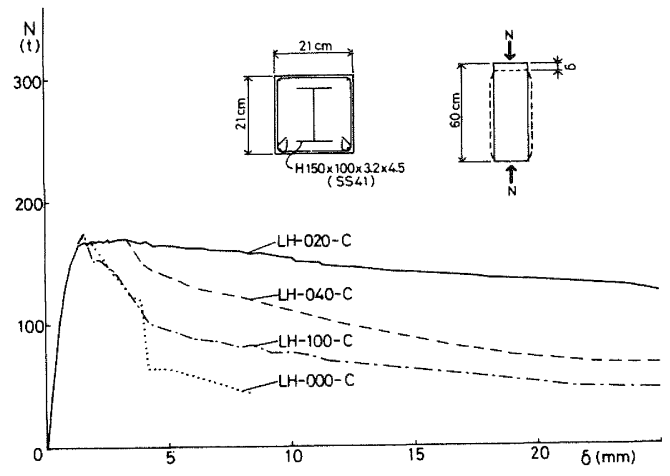

Fig $3 \quad \mathrm{~N}-\delta$ Curves of LH Series

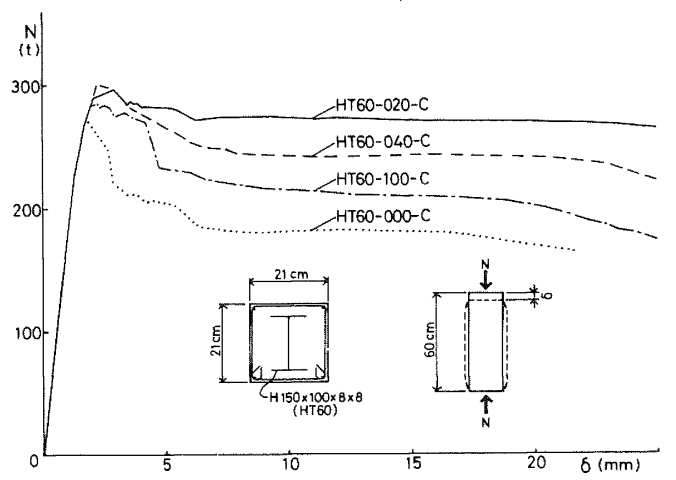

Fig 5 N- $\delta$ Curves of HT60 Series

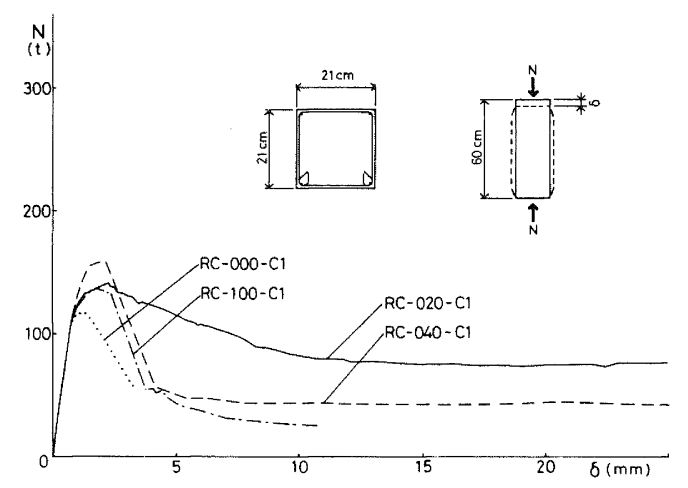

Fig $7 \quad N-\delta$ Curves of RC Series (1)

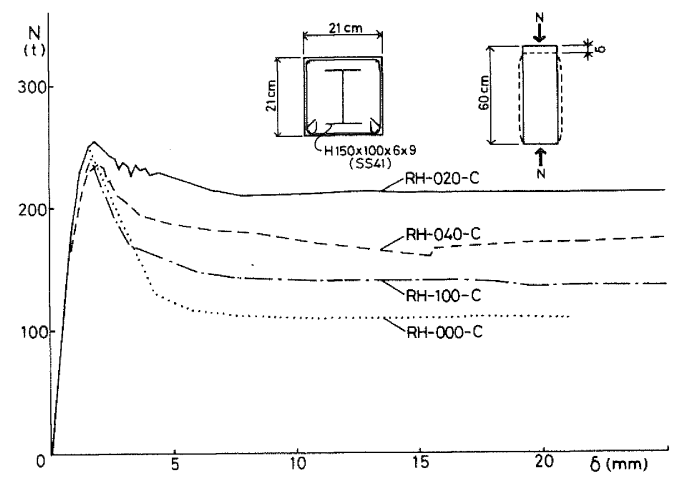

Fig 4 N- $\delta$ Curves of RH Series

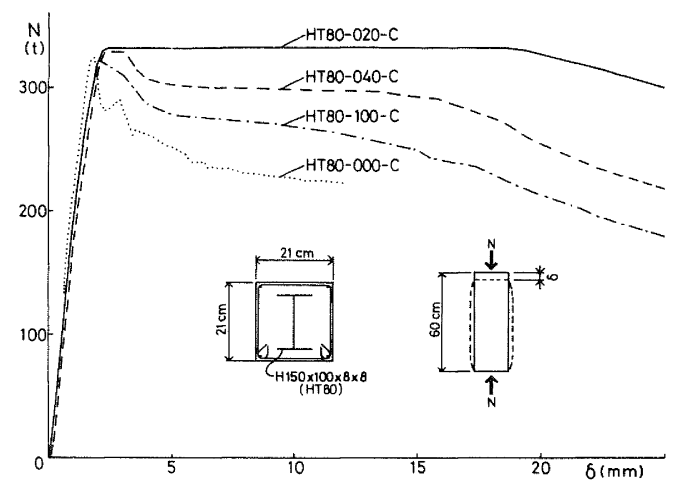

Fig $6 \quad \mathrm{~N}-\delta$ Curves of HT80 Series

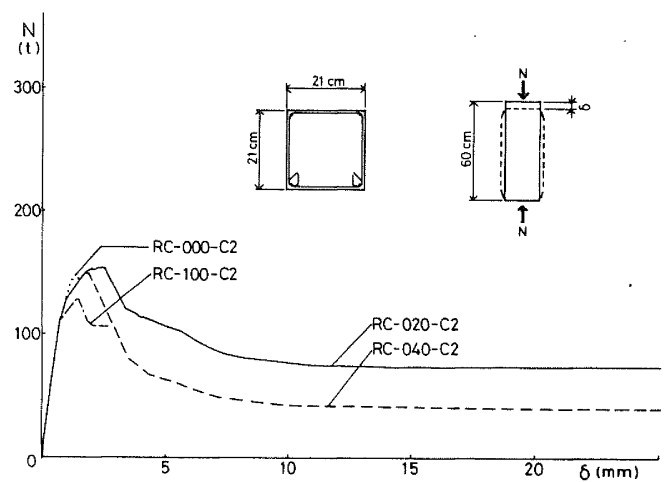

Fig $8 \quad N-\delta$ Curves of RC Series (2) 
strength steel is more difficult than that of normal strength steel; the inelastic strain is apt to concentrate near the critical section, because the strain-hardening of high strength steel is small and the yield zone length should be smaller.

Among the three problems stated above, the preceding two shall be surmounted by the confinement (2) (3) of the concrete by the hoop reinforcement. The investigation of this effect is the main objective of this paper. As for the third problem, the effects of the inelastic strain concentration and the welding are to be discussed by comparing the experimental results of the SRC members of various strength steels.

Variables of the testing are selected as

1. amount of hoop reinforcement

2. the types of $\mathrm{H}$-shaped steel and

3. loading conditions, which include

a) monotonic compression abbreviated as $\mathrm{C}$

b) cyclic bending $B$

c) constant axial force and cyclic bending $\mathrm{CB}$

d) constant axial force and cyclic bending shear CBS and

e) cyclic joint panel shear JPS.

The applicability of the proposed SRC system is investigated in this study. Experiments are carried out about the restoring force characteristics of the proposed SRC system. Effects of hoop reinforcement and steel strength are discussed.

\section{MONOTONIC COMPRESSION TEST}

The test specimens are listed in Table 1. Twenty-four specimens were tested, where the variables were

1. the amount of hoop reinforcement (including no hoop) and

2. the type of $H$-shaped steel (including no steel).

The names of the specimens were determined by the following rules. The first part of the name, LH, RH, HT60 or HT80, indicates the type of the H-shaped steel, that is, lightweight steel with small thickness, rolled steel with larger thickness, 60 $\mathrm{kg} / \mathrm{mm}^{2}$ strength steel, or $80 \mathrm{~kg} / \mathrm{mm}^{2}$ strength steel, respectively. "RC" indicates that H-shaped steel is not used. The second part of the name indicates the spacing of hoop reinforcement in units of $\mathrm{mm}$, except that 000 indicates the specimens without hoop. The third part " $\mathrm{C}$ " indicates that the type of loading is mono tonic compression.

A test specimen example is shown in Figure 1. One set of hoop reinforcement consists of two parts as in Figure 1. Although four round bars of $6 \mathrm{~mm}$ diameter are placed at the corners of the section to support the hoop reinforcement, they were greased and not anchored so that they do not sustain any longitudinal stress. The mechanical properties of steel, reinforcing bar, and concrete are listed in Table 2 and 3 . The age of concrete varies a lot, but the mechanical properties of concrete were almost constant.

The loading and measuring system is illustrated in Figure 2. Spherical bearing was fixed by the adjusting bolts at the earliest stage of the loading. As long as the compressive stiffness of the specimen was high, the loading was controlled by the amount of axial force. After the stiffness had degraded, the loading was controlled by the axial deformation.

Test results are plotted in Figures 3 to 8. The large effects due to the hoop reinforcement can be observed at the descending branch of the N-delta curves to sustain the compressive force after large deformation. At the same time, the existence of $\mathrm{H}$-shaped steel is observed to have a similar effect. For example, the descending stiffness of specimen RC-020C1 or RC-020-C2 is steeper than that of HT80-020-C.

The failure patterns are as follows. After the maximum strength was attained, the cover concrete started to spall and the inclined cracks occurred in every specimen. At large deformations, it appeared that much of the axial deformation was due to the sliding along the inclined cracks. Selected features of the failures after testings are shown in photos 1 and 2 . Feasible two-dimensional deformation patterns after inclined cracks are shown in Figure 9. As shown in Figure 9 (c), if the transverse resistance Nt is present after the diagonal crack, vertical resistance $\mathrm{NV}$ should be larger, in spite of the limited magnitude of $\mathrm{Nf}$.

The effects of the hoop reinforcement upon the axial characteristics of SRC are summarised as follows:

1. to confine the concrete laterally so as to make the axial stress-strain relationship of concrete ductile

2. to restrain the sliding along the inclined cracks and

3. to restrain the local buckling of the steel flange through the surrounding concrete.

Among the three effects stated above, the second effect is also attributable to the H-shaped steel. This explains the ductile behaviour of specimens with $\mathrm{H}$-shaped steel and large amounts of hoop reinforcement. In other words, the axial force-deformation relationship of the SRC member cannot be evaluated as the sum of those of the concrete and the steel.

\section{CYCLIC BENDING TEST}

The test specimens are listed in Table 4. Sixteen specimens were tested, where the variables were

1. the type of $\mathrm{H}$-shaped steel (LH, $\mathrm{RH}$, HT60 or HT80) and 
2. the spacing of hoop reinforcement (20 mm, $40 \mathrm{~mm}, 100 \mathrm{~mm}$, or no hoop).

An example of a test specimen is shown in Figure 10. Dimensions and reinforcement are almost identical to those of the compression test except the end treatment. Mechanical properties of materials are identical to those of the compression test. The loading and measuring system is shown in Figure 11.

Test results of moment-end rotation angle (M-theta) relationships and axial deformation-end rotation angle (dL-theta) relationships are plotted in Figures 12 to 19, among which the figures with even numbers indicate the hysteretic loops and the figures with odd numbers indicate the envelope curves. As for M-theta, the effect of hoop reinforcement is observed to increase the flexural ductility, but is not so significant as in the compression test. As for dL-theta, the larger effect of hoop reinforcement is observed to increase the axial deformation $d L$, which indicates that the neutral axis of the hooped specimen is located more distant from the centroid of the section and that the compressive stress in the concrete was greater.

Examples of specimens after testing are shown in photos 3 and 4 . Local buckling of the steel flange was significant in the specimens without hoop reinforcement. On the other hand, the H-shaped steel in specimens with hoops at $20 \mathrm{~mm}$ pitch was well confined and did not buckle.

Flexural strengths are calculated by Bernoulli-Euler's theorem, assuming that the H-shaped steel is fully plastic and that the compressive stress of the concrete is $0.85{ }^{*} \mathrm{FC}$. The tensile stress of the concrete is ignored. The calculated strengths of $\mathrm{LH}$ and $\mathrm{RH}$ series are $330 t^{*} \mathrm{~cm}$ and $640 t^{*} \mathrm{~cm}$ respectively, both of which are about 1.06 to 1.22 times the observed maximum strengths. The calculated strength of $\mathrm{HT} 60$ and HT80 series are $1070 t^{\star} \mathrm{cm}$ and $1470 t^{\star} \mathrm{Cm}$ respectively, both of which are about 0.94 to 1.04 times the observed maximum strengths. The difference between the normal and the high strength steel is due to the fact that the high strength steel does not have large strainhardening.

CONSTANT AXIAL FORCE AND CYCLIC BENDING TEST

The test specimens are listed in Table 5. Two specimens were tested, where the variable was with or without hoop reinforcement. An example of a test specimen is shown in Figure 19. Dimensions and reinforcements are almost identical to those of the cyclic bending test except the end treatment and the length of the specimen ( $20 \mathrm{~cm}$ longer). Mechanical properties of materials are shown in Tables 6 and 7.

The loading and measuring system is shown in Figure 20. The bending moments were applied to both ends of the specimen independently so that both ends rotated by the same amplitude monitoring the dial gauges Nos 1 and 2 , because it was expected that the moment-curvature relationship of these specimens should be less stable than those of the pure bending test. Axial force was maintained as $\mathrm{N}=50 \mathrm{t}$, which was about 20 percent of the calculated concentric compressive strength.

The loading appartus is more complicated than that for the preceding two test series, because in this test two different forces (axial force and moment) must be applied to the specimen simultaneously. Details of the roller support are shown in Figure 21. Feasible additional moment dM due to the friction at the hinge shaft is discussed as follows considering the equilibrium of forces shown in Figure 22.

1. Axial force $\mathrm{N}$ is applied through the PC bars. The difference between the axial forces carried by the top and bottom bars, $2 * \mathrm{dN}$ was around $3.0 \mathrm{t}$ or less. This creates the first component of the feasible additional moment $\mathrm{dM} 1=\mathrm{dN} * 20 \mathrm{~cm}=30 \mathrm{t} * \mathrm{~cm}$.

2. Shear force $P$ is applied by the hydraulic jack and is measured by the load cell. The maximum value of $P$ was about 13t. Corresponding reaction force $\mathrm{P}$ is transmitted through the slide needle bearing. We may assume the deviation $e$ of the location of $P$ from the centre of the hinge shaft is less than $2 \mathrm{~cm}$, which is about onequarter of the width of the bearing. This yields the second component of the feasible additional moment, $\mathrm{dM} 2=\mathrm{P}^{*} \mathrm{e}=26 \mathrm{t}^{*} \mathrm{Cm}$.

3. The friction coefficient of the needle bearing $c$ can be considered less than 0.02 , so the friction $F=c * P$ is less than 0.3t. This yields the third component $\mathrm{dM} 3=\mathrm{F} * 19 \mathrm{~cm}=6 \mathrm{t} * \mathrm{~cm}$.

Consequently, the additional moment dM, which cannot be measured by this loading system, is evaluated as less than $62 t * \mathrm{~cm}$. This is about 6 percent of the measured maximum strength of the specimens. $d M$ is transmitted to the specimen through the frictional force at the hinge shaft. The frictional coefficient of the hinge shaft to transmit $d M=62 t^{\star} \mathrm{cm}$ is evaluated as 0.2 .

Test results are plotted in Figures 7 and 8. The $N$-delta effect is evaluated by the equation $-\mathrm{dM}=50 \mathrm{t} * 80 \mathrm{~cm} *$ theta $/ 8$ in Figure 23 if the curvature is assumed to distribute uniformly, or by the equation $-\mathrm{dM}=50 \mathrm{t} * 80 \mathrm{~cm} *$ theta $/ 4$ if the curvature is assumed to concentrate at the middle of the specimen. The specimens after testing are shown in photos 5 and 6 .

Large effects of hoop reinforcement were observed in this test series. The specimen with $20 \mathrm{~mm}$ pitched hoops showed a stable spindle shaped hysteresis loop. Although the shell concrete spalled almost completely, the core concrete did not spall. The maximum strength of the specimen without hoop was about 80 percent of that of the hooped specimen. The concrete started to crush and spall at theta 
Table 5 List of Compression-Bending Specimens

\begin{tabular}{|c|c|c|c|}
\hline $\begin{array}{l}\text { Hoop Reinforcements } \\
(\mathrm{mm})\end{array}$ & $-6 \phi-20$ & no hoop & $\begin{array}{l}\text { Axial Force } \\
\text { (ton) }\end{array}$ \\
\hline H $\begin{array}{c}150 \times 100 \times 5 \times 5 \\
(\mathrm{HTRO})\end{array}$ & $\begin{array}{l}\begin{array}{l}\text { HT80-020-CB-20 } \\
(137)\end{array} \\
\end{array}$ & $\begin{array}{l}\text { HT80-000-CB-20 } \\
(140)\end{array}$ & 50 \\
\hline $\begin{array}{l}\text { Nominal size of } \\
\text { H-shaped Steel } \\
\text { Section (mm) } \\
\text { (Standardized } \\
\text { Classification } \\
\text { of Steel) }\end{array}$ & $\begin{array}{l}\text { Name of specimer } \\
\text { [Cormon I tems] } \\
\text { Section of } \\
\text { Date of Con } \\
\text { Maximum Size }\end{array}$ & $\begin{array}{l}\text { Age of the con } \\
\text { specimen was } t \\
\text { cimen : } 21 \mathrm{~cm} \times 21 \mathrm{c} \\
\text { te Placing : March } \\
\text { f Coarse Aggregate }\end{array}$ & $\begin{array}{l}\text { ete when the } \\
\text { ted (days) }\end{array}$ \\
\hline
\end{tabular}

Table 6 Mechanical Properties of Steel and Reinforcing Bar in Compression-Bending Test and Compression-BendingShear Test Specimens

\begin{tabular}{|c|c|c|c|c|}
\hline \multirow{3}{*}{$\begin{array}{l}\text { Standardized Classification } \\
\text { Noninal Thickness or } \\
\text { Diameter (mm) }\end{array}$} & \multicolumn{3}{|c|}{ Steel Pla.te } & \multirow{3}{*}{$\begin{array}{l}\begin{array}{l}\text { Reinforcing } \\
\text { Bar }\end{array} \\
\text { SR24 } \\
6\end{array}$} \\
\hline & \multicolumn{2}{|c|}{5541} & HT80 & \\
\hline & 3.2 & 4.5 & 5 & \\
\hline $\begin{array}{l}\text { Actual Thickness or } \\
\text { Diameter }(\mathrm{mm})\end{array}$ & 3.03 & 4.34 & 5.50 & 5.43 \\
\hline Yield Strengtii (ton $/ \mathrm{cm}^{2}$ ) & 3.48 & 3.48 & 7.79 & 3.41 \\
\hline Tensile Strength (ton $/ \mathrm{cm}^{2}$ ) & 4.62 & 4.56 & 8.32 & 4.40 \\
\hline $\begin{array}{l}\text { Strain at the Onset of } \\
\text { Strain Hardening (:) }\end{array}$ & 2.2 & 2.0 & $\begin{array}{l}2.0 \\
\sim 2.4\end{array}$ & 0.8 \\
\hline Elongation (:) & 40.2 & 40.3 & 24.0 & 28.5 \\
\hline $\begin{array}{l}\text { Diniensions of Test Piece } \\
\text { (J1S Z 2201) }\end{array}$ & No. 5 & No. 5 & No.7 & No. 2 \\
\hline
\end{tabular}

Table 7 Mechanical Properties of Concrete in Compression-Bending Test and Compression-BendingShear Test Specimens

\begin{tabular}{|c|c|c|c|c|c|}
\hline Age (days) & 60 & 83 & 06 & 103 & 143 \\
\hline $\begin{array}{l}\text { Compressive Strength } \\
\mathrm{Fc}\left(\mathrm{kg} / \mathrm{cm}^{2}\right)\end{array}$ & 346 & 380 & 311 & 303 & 312 \\
\hline $\begin{array}{l}\text { Splitting Tensile } \\
\text { Strength }\left(\mathrm{kg} / \mathrm{cm}^{2}\right)\end{array}$ & 31.4 & 31.8 & 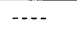 & 30.9 & 31.7 \\
\hline $\begin{array}{l}\mathrm{Fc} / 3 \text { Secant Modulus } \\
\left(10^{5} \mathrm{~kg} / \mathrm{cm}^{2}\right)\end{array}$ & 2.5 & 2.6 & 2.3 & 2.2 & 2.4 \\
\hline $\begin{array}{l}\text { Strain at the } \\
\text { Maximum Stress (1) }\end{array}$ & $\begin{array}{l}0.25 \\
\sim 0.30\end{array}$ & $\stackrel{0.26}{\sim 0.31}$ & $\begin{array}{l}0.27 \\
\sim 0.31\end{array}$ & $\begin{array}{l}0.23 \\
\sim 0.29\end{array}$ & $\stackrel{0.24}{\sim 0.30}$ \\
\hline Date of Placing & \multicolumn{2}{|c|}{ September 8,1981} & \multicolumn{3}{|c|}{ March 15,1982} \\
\hline$w / C()$ & \multicolumn{2}{|c|}{61.0} & \multicolumn{3}{|c|}{66.0} \\
\hline Slump $(\mathrm{cm})$ & \multicolumn{2}{|c|}{15} & \multicolumn{3}{|c|}{18} \\
\hline
\end{tabular}

Table 8 List of Compression-Bending-Shear Specimens

\begin{tabular}{|c|c|c|c|c|}
\hline \multirow[t]{2}{*}{$\begin{array}{l}\text { Hoop Reinforcements } \\
(\mathrm{mm})\end{array}$} & \multicolumn{4}{|c|}{$\begin{array}{l}\text { Nominal Size of H-shaped Steel Section (mm) } \\
\text { (Standardized Classification of Steel) }\end{array}$} \\
\hline & \multicolumn{3}{|c|}{ i. $\begin{array}{c}150 \times 100 \times 3.2 \times 4.5 \\
(5547)\end{array}$} & 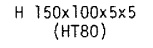 \\
\hline$C_{6}-020$ & $\begin{array}{l}\text { LH-020-CBS-00 } \\
(50-51)\end{array}$ & $\begin{array}{l}\text { LH-020-CBS-20 } \\
(62-63)\end{array}$ & - n- & $\begin{array}{l}\text { HT } 80-020-\text { CBS }-20 \\
(71-79)\end{array}$ \\
\hline $6 ;-\theta 40$ & & $\begin{array}{l}\text { LH- } 040-\mathrm{CBS}-20 \\
(69-70)\end{array}$ & $\begin{array}{l}\text { ㄴHH-040-CBS-33 } \\
(72-73)\end{array}$ & $\begin{array}{l}\text { HT } 80-040-\text { CBS }-20 \\
(99)\end{array}$ \\
\hline 6:- a 100 & & $\begin{array}{l}\text { LH-100-CBS-20 } \\
(66-67)\end{array}$ & $\begin{array}{l}\text { LH- } 100-C B S-33 \\
(77-78)\end{array}$ & $\begin{array}{l}\text { HT80-100-CBS-20 } \\
(92-94)\end{array}$ \\
\hline no hoop & 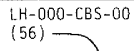 & $\begin{array}{l}\text { LH-000-CBS-20 } \\
(64-65)\end{array}$ & 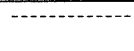 & $\begin{array}{l}\text { HT80-000-CBS-20 } \\
(85-86)\end{array}$ \\
\hline Axidal Force (ton) & 0 & 36 & 60 & 50 \\
\hline $\begin{array}{l}\text { Date of Concrete } \\
\text { Placing }\end{array}$ & \multicolumn{3}{|c|}{ September 8,1981} & March 15, 1982 \\
\hline \multicolumn{5}{|c|}{$\begin{array}{l}\text { CName of Specimen } \\
\text { the concrete when the specimen was tested (days) }\end{array}$} \\
\hline
\end{tabular}




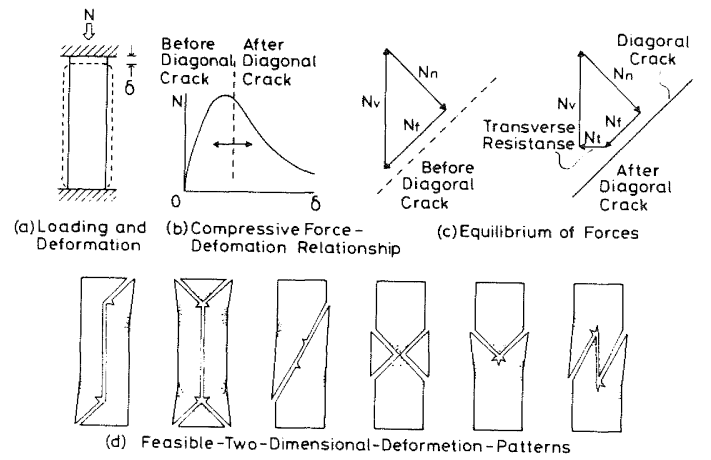

Fig 9 Compressive Deformation Mechanism
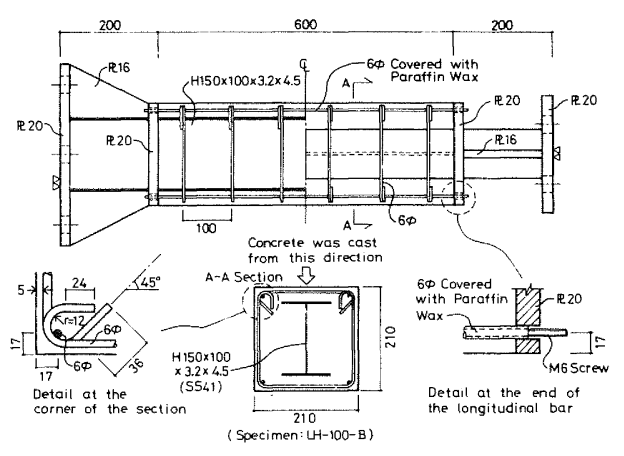

Fig 10 An Example of

Bending Test Specimen

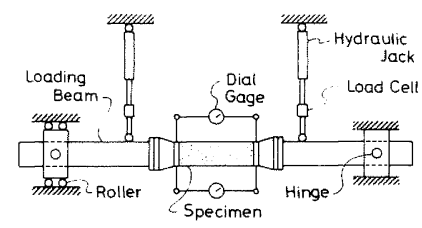

Fig 11 Loading and Measuring System of Bending Test

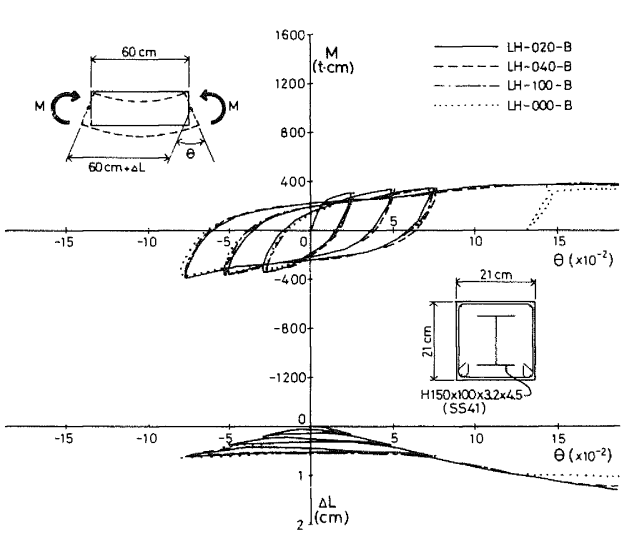

Fig $12 \quad \mathrm{M}-\theta$ and $\Delta \mathrm{L}-\theta$ Hysteresis Curves of LH Series

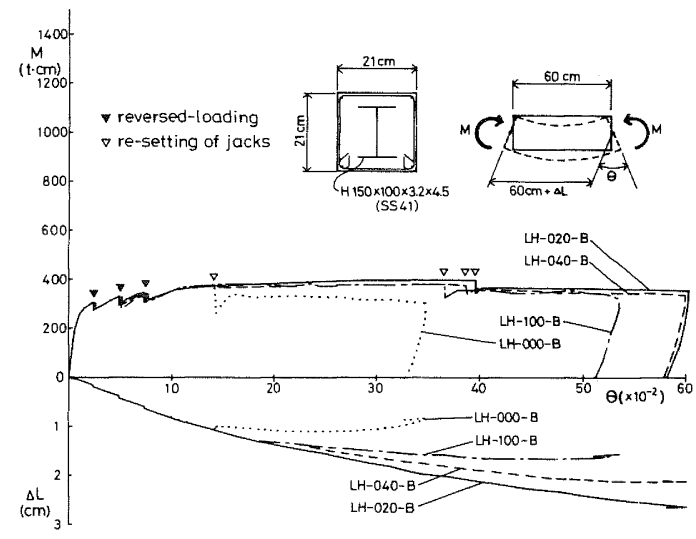

Fig $13 \quad \mathrm{M}-\theta$ and $\Delta \mathrm{L}-\theta$ Skeleton Curves of LH Series

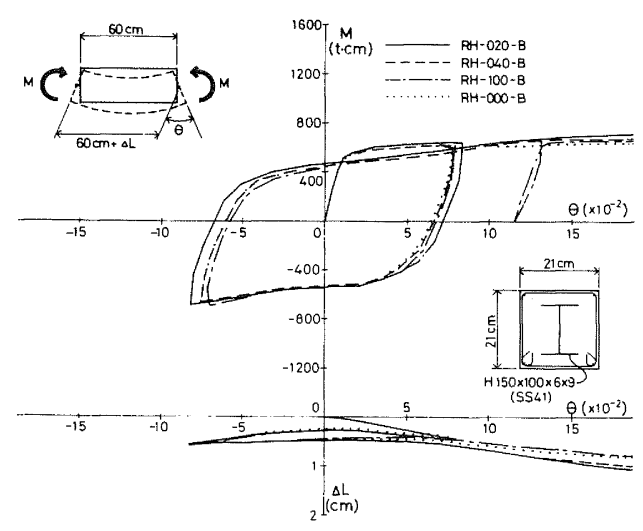

Fig $14 \quad M-\theta$ and $\Delta L-\theta$ Hysteresis Curves of RH Series

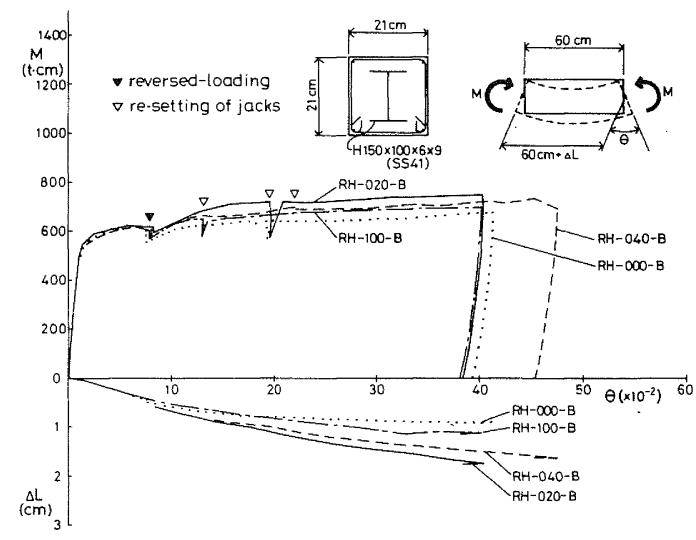

Fig $15 \mathrm{M}-\theta$ and $\Delta \mathrm{L}-\theta$ Skeleton Curves of $\mathrm{RH}$ Series 


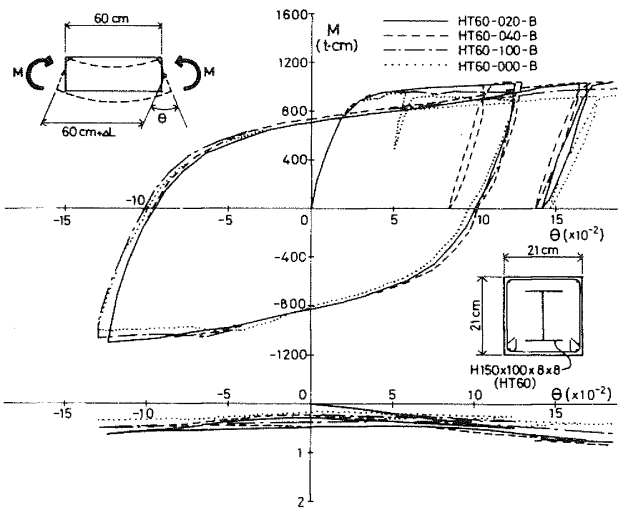

Fig $16 \quad M-\theta$ and $\Delta L-\theta$ Hysteresis

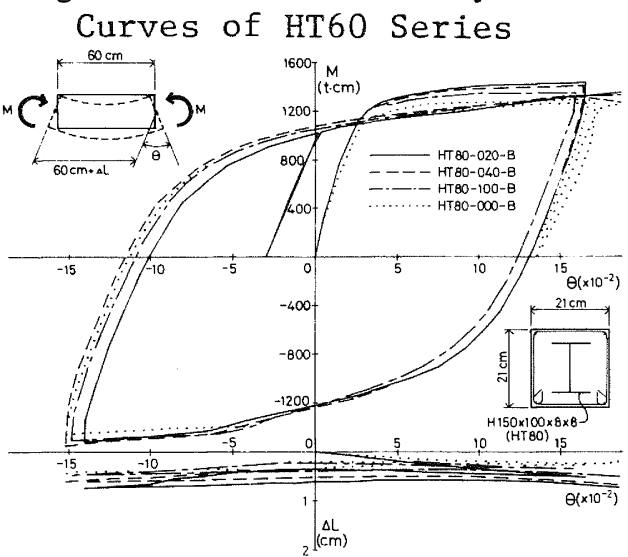

Fig $18 \mathrm{M}-\theta$ and $\Delta \mathrm{L}-\theta$ Hysteresis Curves of HT80 Series

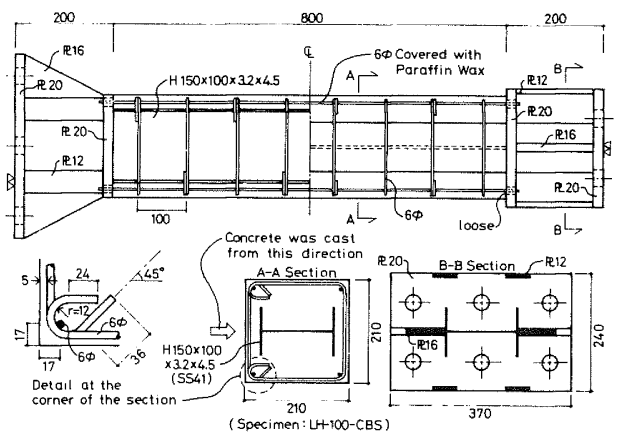

Fig 20 An Example of $C B$ and CBS Series Specimen

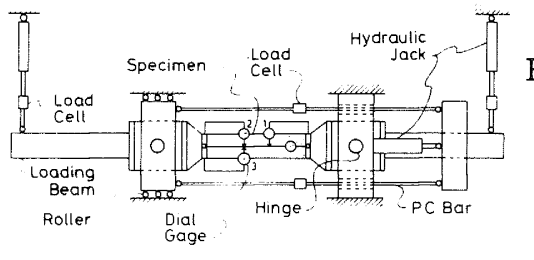

Fig 21 Loading and Measuring System of $C B$ and CBS Test Series

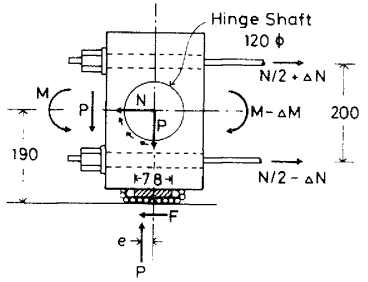

Fig 23 Equilibrium of Forces around Roller Support

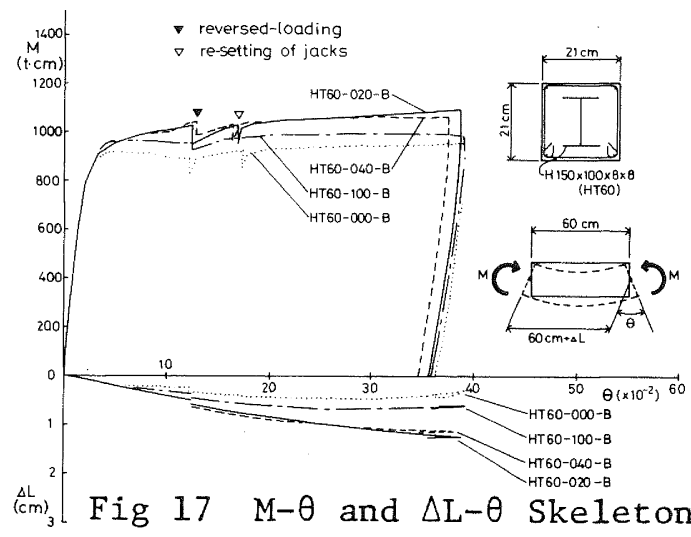
Curves of HT60 Series

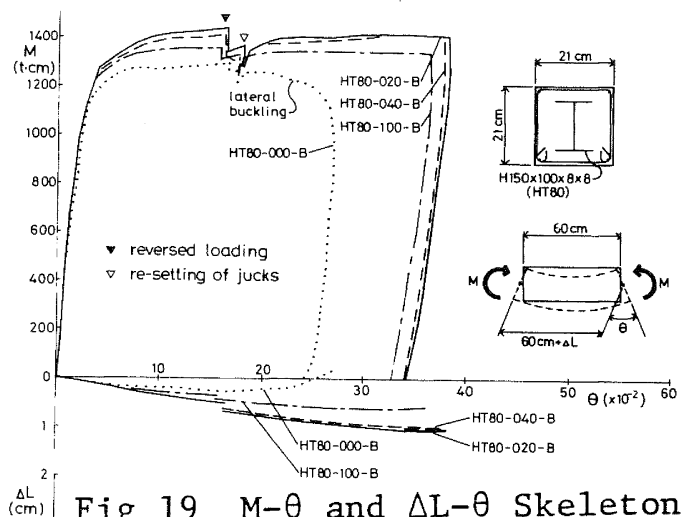
Curves of HT80 Series
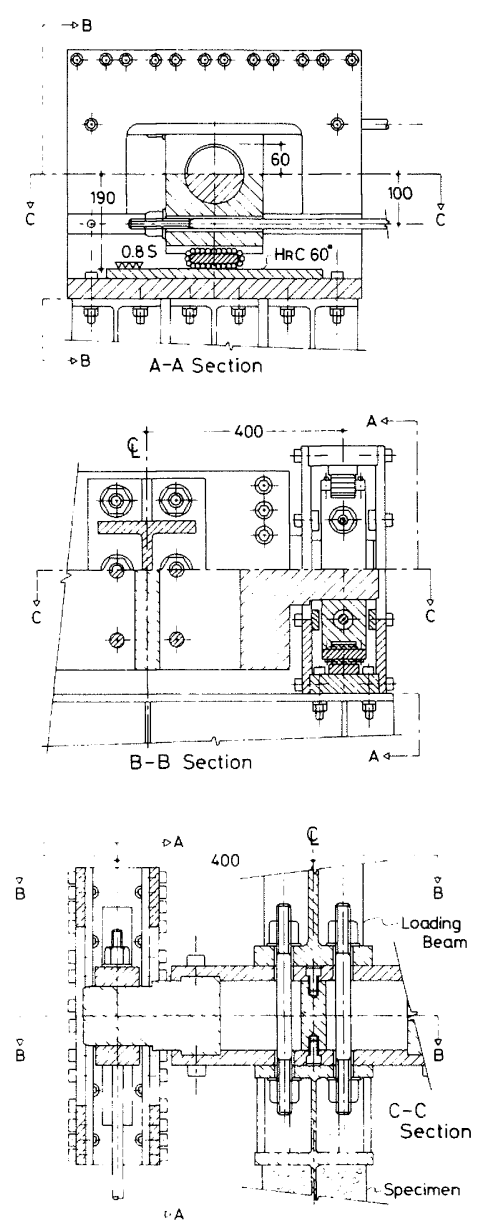

Fig 22 Detail of Roller Support 
$0.04 \mathrm{rad}$. Local buckling of the steel flange was observed at theta $=0.10 \mathrm{rad}$, and after that, the compressive axial deformation became large. When the negative moment was applied, the degradation of the strength became more significant. At theta $=0.15 \mathrm{rad}$, the moment resistance of the specimen was completely lost, and the loading was terminated.

Location of the neutral axis was calculated from the data of end rotation angle and axial deformation, assuming the uniform distribution of the curvature. The results are shown in Figures 25 and 26 . The neutral axis of the hooped specimen stayed near the section centroid when theta was large. The neutral axis of the unhooped specimen was located out of the section when the negative moment was applied.

Moment-rotation angle relationships of both specimens were calculated assuming the uniform distribution of curvature and considering the equilibrium of moment at the centre of the specimen, that is, the $\mathrm{N}$-delta effect was assumed as -dM= $50 \mathrm{t} * 80 \mathrm{~cm} *$ theta/8. Stress-strain relationship of steel was assumed as perfectly elasto-plastic, because strain-hardening of HT80 is small. Tensile stress of concrete was neglected. Compressive stressstrain relationship of concrete was assumed as follows (see Figure 27):

1. Until the maximum strength $\mathrm{FC}$ was attained, a parabolic relationship was assumed, where FC and strain at FC were determined from the data in Table 7 irrespective of whether it was with or without reinforcement;

2. After FC, the stress-strain relationship was assumed as linear, where the descending stiffness was determined from the monotonic compression test data as shown in Figure 27;

3. After $0.2 \times \mathrm{FC}$, the stress was assumed as constant.

Calculated results are plotted in Figure 29. They show a good agreement with experimental results in Figure 24.

CONSTANT AXIAL FORCE AND CYCLIC BENDING SHEAR TEST

The test specimens are listed in Table 8. Twelve specimens were tested, where the variables were:

1. the amount of hoop reinforcement

2. the type of H-shaped steel and

3. the amount of axial force.

The number placed at the end of the specimen's name, such as 00,20 or 33 , indicates the percentage ratio of the applied axial force to the calculated concentric compression strength. The mechanical properties of the materials and the loadingmeasuring system are identical to those for the preceding test series. The feasible error of measured load due to the friction at the hinge shaft is evaluated by the similar consideration to that in the previous section. It was estimated as less than 7 percent of the measured maximum strength of the specimens. This percentage is almost the same as that of the previous test series. The antisymmetric deformation was applied to both ends of the specimen monitoring the dial gauges Nos 1 and 3 in Figure 20. The deflection angle amplitude of the cyclic loading was selected as 1/80rad and $1 / 40$ rad.

As a preparatory testing, the bare $\mathrm{H}$-shaped normal and high strength steel were tested without axial force. Test results are shown in Figures 31 and 32 , in which the calculated full plastic strengths are indicated as Mp. The difference between the calculated and observed strengths is about 8 percent in both specimens, and is attributable to the friction at the hinge shaft, the welding bead at the critical section, and the strain-hardening of the steel.

Test results of $\mathrm{LH}-* \star \star *-\mathrm{CBS}-000$ series, which were loaded without axial force, are shown in Figures 33 and 34 . Test results and test observations were almost the same for both specimens, except that the axial deformation of the hooped specimen was greater than that of the nonhooped specimen. The deflection of both specimens was induced by the flexural cracks at the critical sections almost exclusively. Inclined cracks were not observed as was expected (see Introduction). The crushing of concrete was limited within a small region near the critical section. The fracture of tension flange induced the strength degradation.

Test results of $\mathrm{LH}-\star \star \star * \mathrm{CBS}-20$ series with an axial force 20 percent of the calculated concentric strength, are shown in Figures 35 and 36, where the N-delta effect is indicated by the equation -dQ $=50 t *$ delta $/ 80 \mathrm{~cm}$. The maximum strengths were not much affected by the hoop reinforcement. The strength of the specimen without hoop reinforcement degraded largely due to the crushing and spalling of concrete and the local buckling of the steel. The crushed region of the concrete was wider in the lesser hooped specimen. Inclined cracks were not observed. After the test, the concrete was removed to investigate the features of the steel. Local buckling of the compressive steel flange was observed in all the specimens except the most densely hooped specimen LH-020-CBS-20. The tensile fracture of the flange was not observed in any specimen.

Test results of $\mathrm{LH}-* * *-\mathrm{CBS}-33$ series with axial force 33 percent of the calculated concentric strength are shown in Figures 37 and 38. Again the hoop reinforcement did not affect the maximum strength much, but affected the ductility a lot. Diagonal cracking was observed in LH-100-CBS-33. Local buckling of the compressive steel flange was observed in both specimens.

Test results of HT80-***-CBS-20 series with axial force 20 percent of the calculated concentric strength are shown in Figures 39 and 40. Examples of specimens 


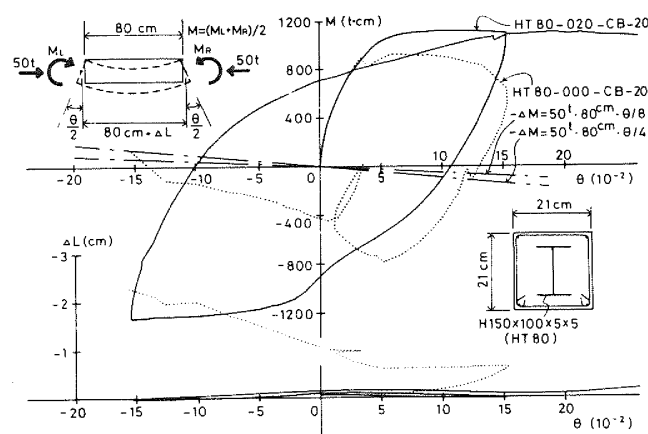

Fig $24 \quad M-\theta$ and $\Delta L-\theta$ Hysteresis

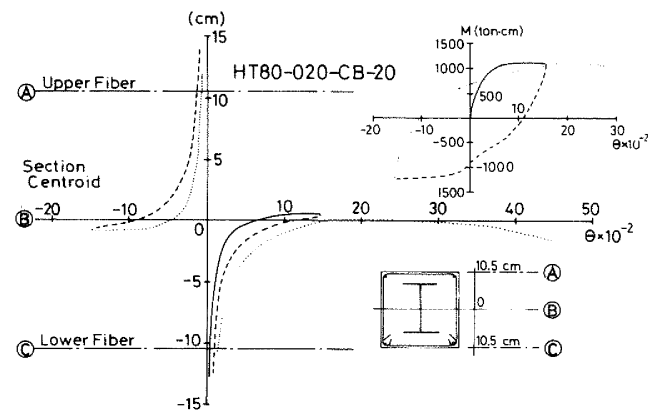

Fig 26 Hysteresis of Neutral Axis (HT80-020-CB-20).

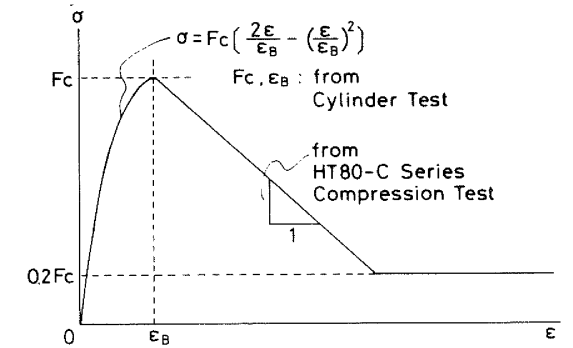

Fig 28 Assumed Stress Strain of Concrete

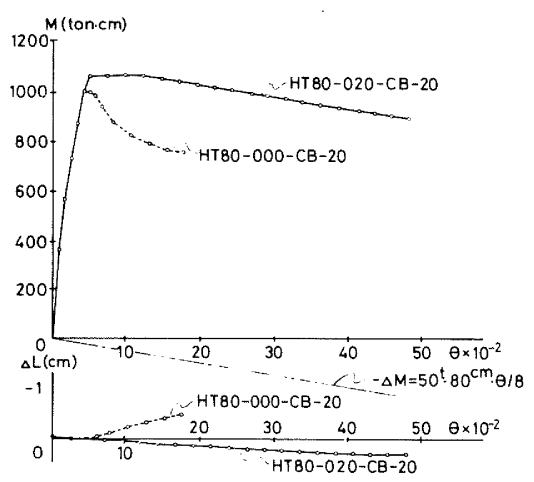

Fig 30 Calculated M- $\theta$ CUrves

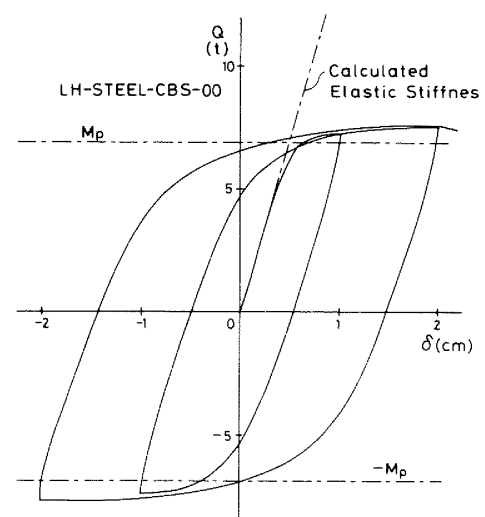

Fig 31 Q- $\delta$ of LH Steel

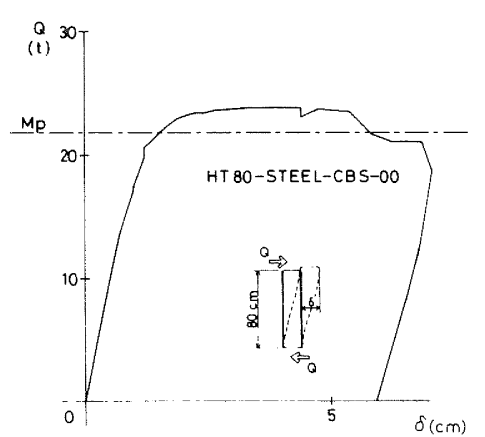

Fig 32 Q- $\delta$ of HT80.Fig 33 Q- $\delta$ Hysteresis Stee1

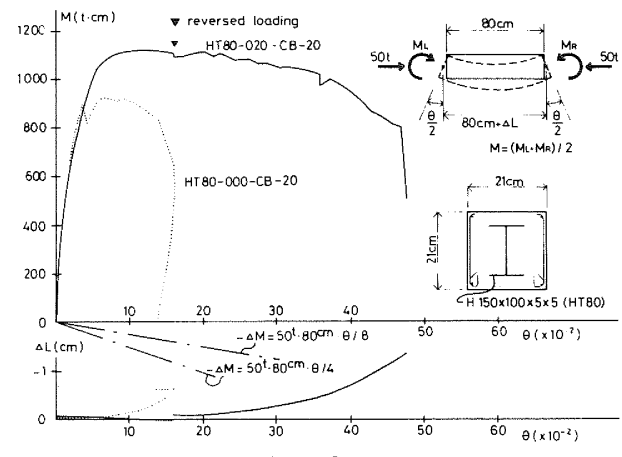

Fig $25 \mathrm{M}-\theta$ and $\Delta \mathrm{L}-\theta$ Skeleton Curves

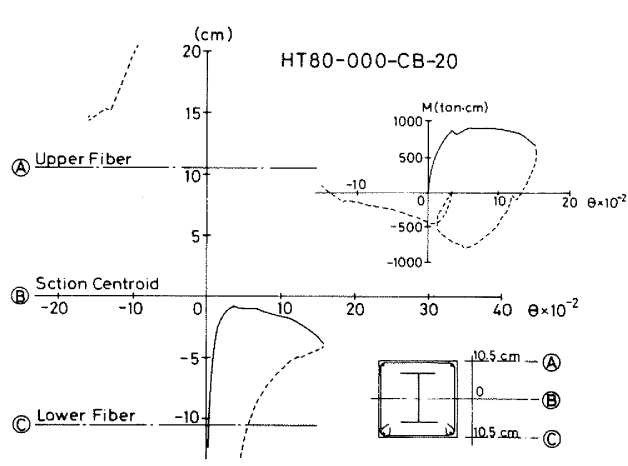

Fig 27 Hysteresis of Neutral Axis (HT80-000-CB-20)

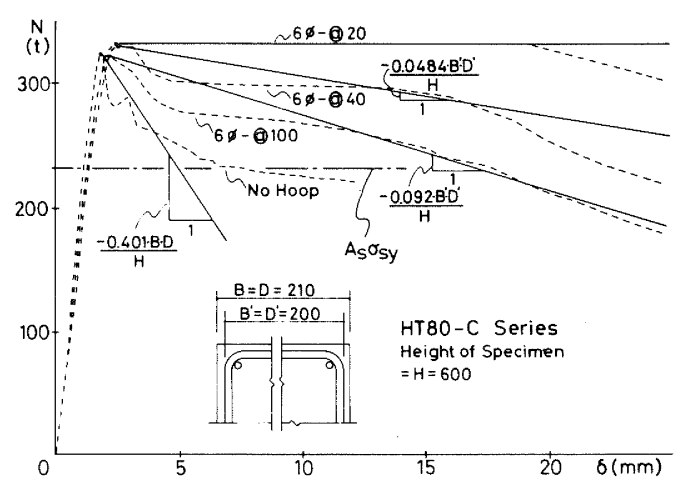

Fig 29. Assumed Descending Stiffness of Concrete

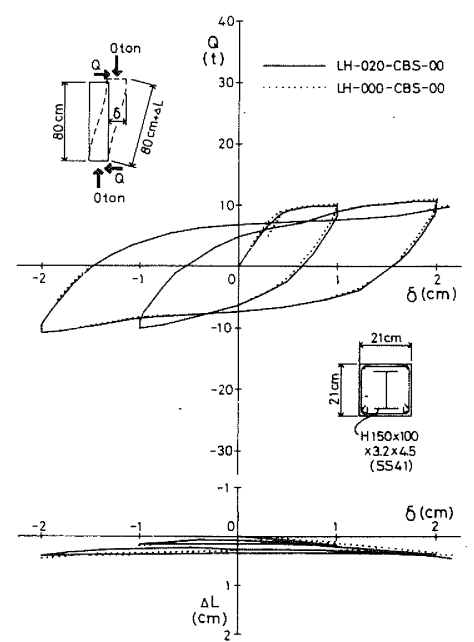
of $\mathrm{LH}-* * *-\mathrm{CBS}-00$ Series 


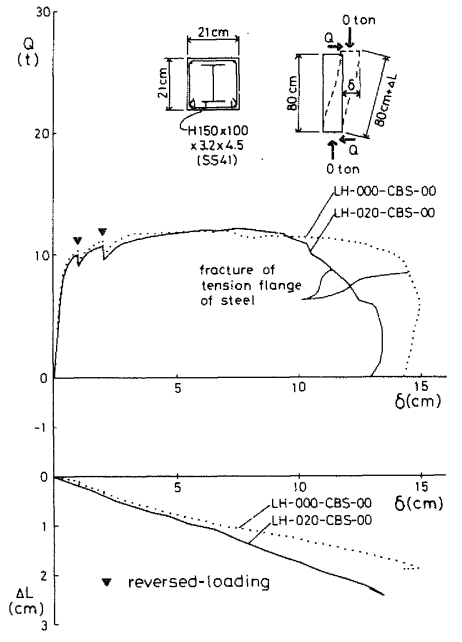

Fig 34 Q- $\delta$ Skeleton of LH-***-CSB-00 Series
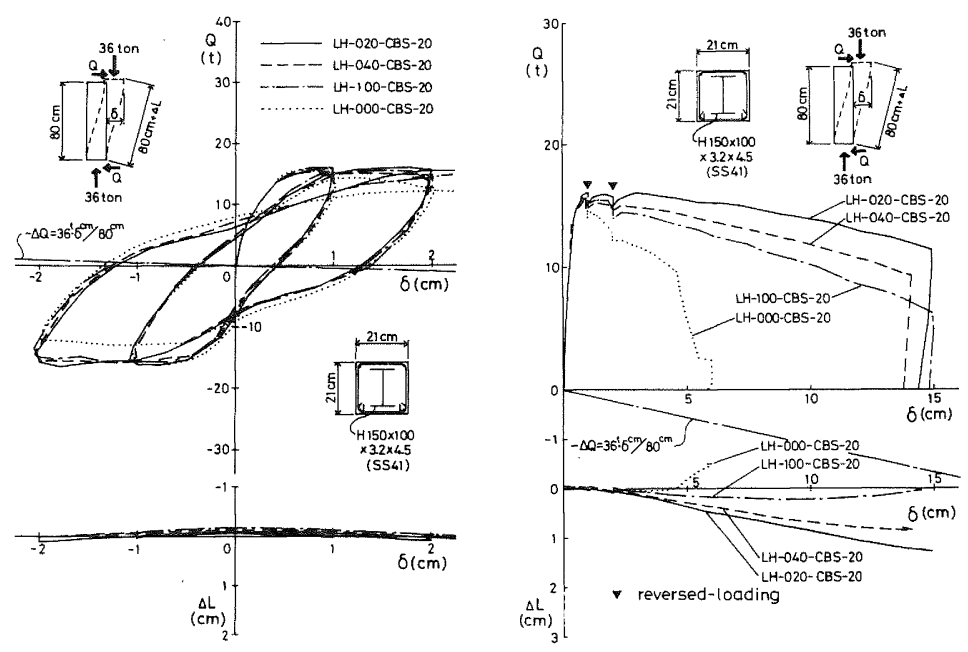

Fig 35 Q- $\delta$ Hysteresis Fig 36 Q- $\delta$ Skeleton of LH- $* * *-C B S-20$ Series of LH- $* * *-C B S-20$ Series

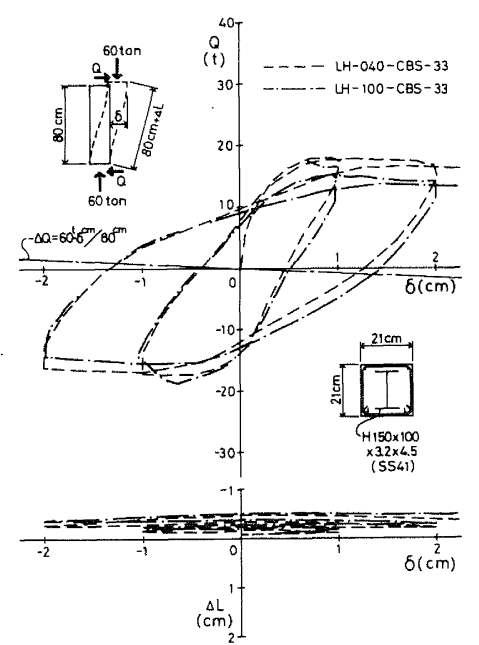

Fig 37 Q- $\delta$ Hysteresis of LH-***-CBS-33 Series

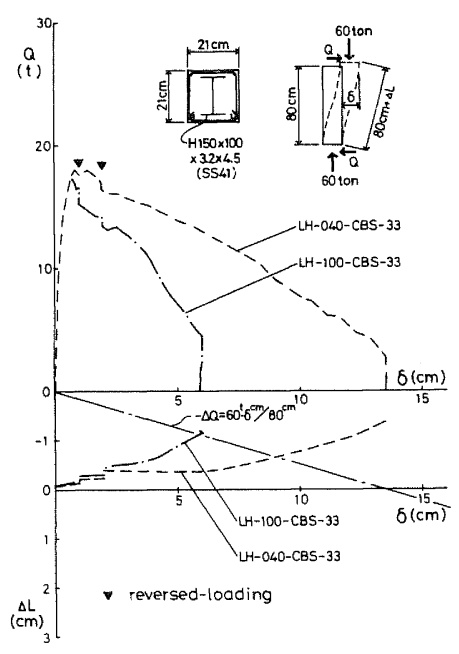

Fig 38 Q- $\delta$ Skeleton of $\mathrm{LH}-\star \star \star * *-C B S-33$ Series

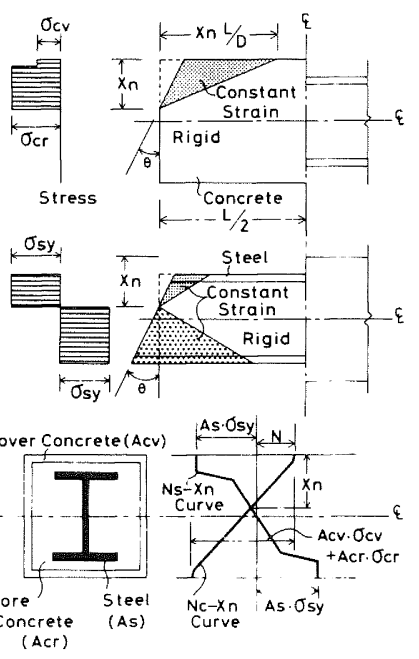

Fig 41 Uniform Strain Model

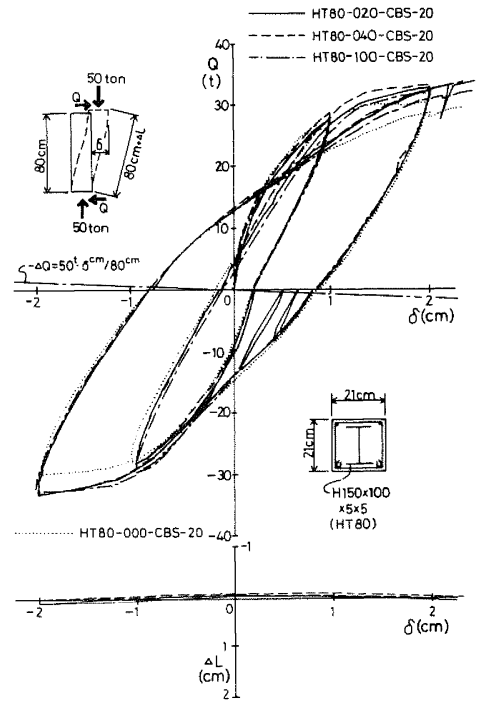

Fig 39 Q- $\delta$ Hysteresis of HT80-***-CBS-20 Series

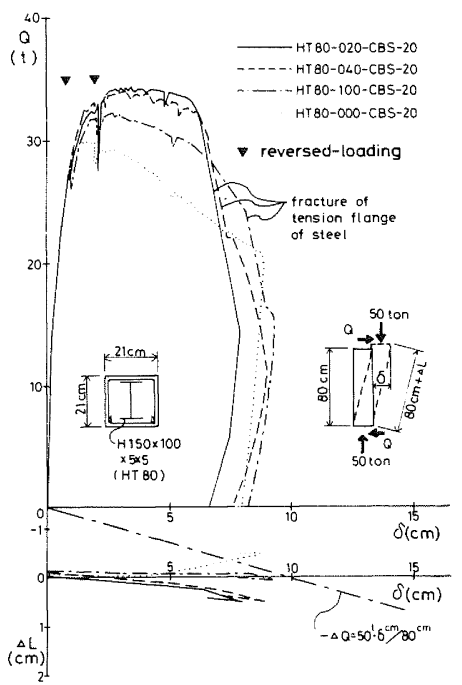

Fig 40 Q- $\delta$ Skeleton of HT80-***-CBS-20 Series

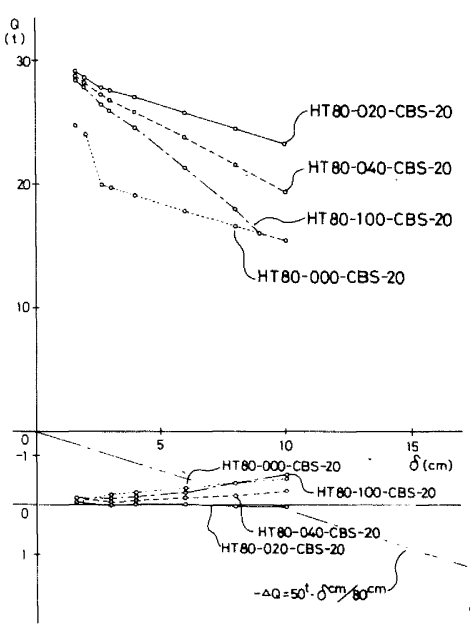

Fig 42 Calculated $0-\delta$ Curves of HT 80-***-CBS-20 Series 
after testing are shown in photos 7 and 8. In all the specimens, flexural cracks concentrated at the critical section as was expected. Flexural shear cracking was not observed. Local buckling of steel and diagonal cracking of concrete were observed in the specimen without hoop reinforcement.

When we compare these test results with those of LH-***-CBS-20 series (normal strength steel), two remarkable features are noted.

1. The maximum strength as well as the descending stiffness was affected by the hoop reinforcement in this test series. The strength of the unhooped specimen was 80 percent of that of the $20 \mathrm{~mm}$-pitch hooped specimen. This indicates that the role of the hoop reinforcement is more important in the high strength SRC member.

2. The strength of all the specimens degraded largely by the fracture of the tension flange of steel at delta = $6 \mathrm{~cm}$ to $8 \mathrm{~cm}$ (deflection angle = $1 / 13 \mathrm{rad}$ to $1 / 10 \mathrm{rad})$. This is attributable to the inelastic strain concentration (see Introduction). Although the deflection angle at the fracture was large, the considerable strength degradation should be regarded as the defect of the proposed SRC system. If we design the especially ductile member such as the bottom part of the first storey column, we must contrive a new way to surmount it; for example, the steel flange shall be tapered so that the inelastic strain shall distribute wider and shall not concentrate near the critical section. The applicability of such a method must be verified by experiments in the near future.

When we compare these test results with those of HT80-***-CB-20 series (constant axial load and cyclic bending), it is noted that the critical sections of the CBS series specimens sustained larger moment than those of $\mathrm{CB}$ series. Assuming that the $\mathrm{N}$-delta effect of the CB series specimens lies between the two equations in Figure 24 or 25, moment capacities of H'T-020-CBS-20 and HT80-000-CBS-20 at the critical sections are evaluated as 1.11.2 times and 1.2-1.3 times of those of the corresponding $C B$ series specimens, respectively. This difference is attributable to the fact that the crushed regions of the CBS series specimens were smaller than those of the corresponding $\mathrm{CB}$ series as indicated in photos 5 to 8; the neighbouring solid concrete should have restrained the crushing in the CBS series specimens.

A compatible deformation model of the proposed SRC member subjected to bending shear is shown in Figure 41. Flexural cracks of concrete are assumed to concentrate at both ends of the member. Constant strain regions for concrete and steel are assumed. Outside of these regions, both concrete and steel are assumed as rigid. The stress-strain relationship of concrete within the constant strain region is assumed as identi- cal to those in the previous section (see Figures 28 and 29). Steel is assumed as perfectly rigid-plastic. It should be noted that this model gives a larger flexural strength than the usual BernoulliEuler's theorem, because the compressive stress distribution can be uniformly FC. The distance of the neutral axis from the compressive fibre $\mathrm{Xn}$ can be evaluated geometrically as indicated in the lowest part of Figure 41.

Calculated Q-delta and dL-delta relationships are shown in Figure 42. Although the results show qualitative agreement with the test results, the calculated strengths are still lower than the observed.strengths. The compressive stressstrain relationship of concrete in the members subjected to bending-shear should be affected by the restraint of the neighbouring solid concrete, and be different from that subjected to bending.

\section{CYCLIC JOINT PANEL SHEAR TEST}

The test specimens are listed in Table 9. Four specimens were tested where the variables were:

1. the type with H-shaped steel (SS41 or HT80) and

2. with or without hoop reinforcement.

An example of the test specimen and its detail is shown in Figures 43 and 44 . The beams are bare $\mathrm{H}$-shaped steel. The sections of the columns are similar to those of the preceding RH or HT80 series except that the thickness of the flange for the SS41 series is 1.3 times that for the RH series. The H-shaped steel of the column was continued through the joint; the beams and the stiffners were welded to the column. The hoop reinforcement was assembled through the slender holes of the beam webs. The joint panel was designed as the weakest; the column was designed stronger than the joint panel but weaker than the beam. (In the design of the actual structures, the order of the strengths shall be the opposite.) Mechanical properties of materials are listed in Tables 10 and 11 .

The loading apparatus of the preceding test series was modified a little and used for this test series. The loading and measuring system is shown in Figure 45 . Axial force is not applied in this test. Dial gauge holders were supported by bolts of $12 \mathrm{~mm}$ diameter (see Figure 44). The bolts were welded to the stiffners and flanges, and insulated from the concrete by holes of $30 \mathrm{~mm}$ diameter. Two sets of measuring systems were attached to both sides of the specimen. The measured values of shear deformation angle gamma at both sides were averaged.

The joint panel moment PM is defined by the following equation considering the equilibrium of forces in Figure 46.

$P M=\left(Q B+Q B^{\prime}\right) \star\left(h *(l+J C)-J C^{\star}(h+J b)\right) /(h+J b)$

Test results of Piv-gamma relationships are shown in Figures 47 to 50 . Examples 
Table 9 List of Joint-Panel-Shear Test Specimens

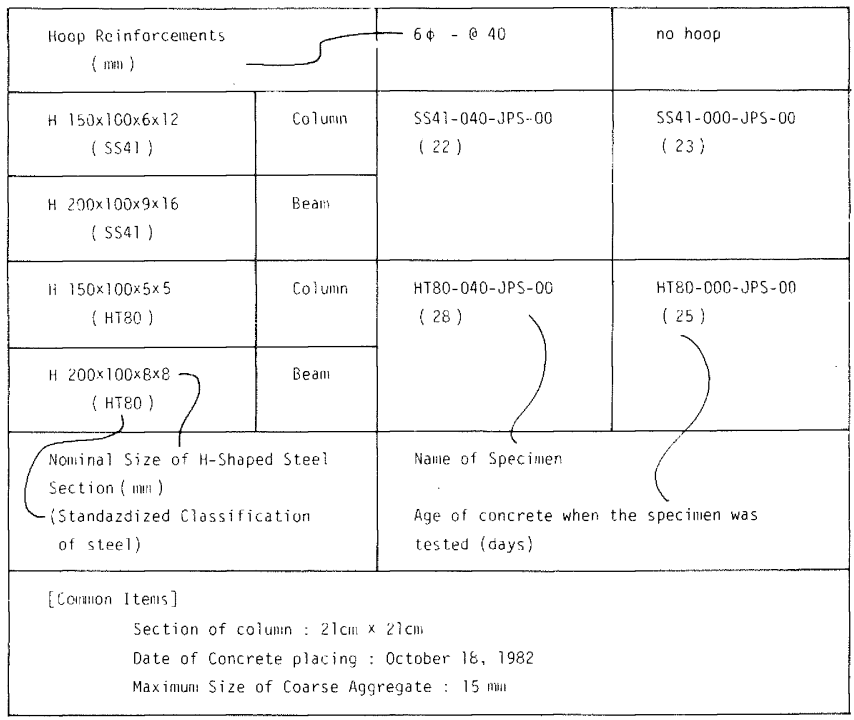

Table 10 Mechanical Properties of Steel and Reinforcing Bar in Joint-Panel-Shear Test Specimens

\begin{tabular}{|c|c|c|c|c|c|c|c|}
\hline \multirow{3}{*}{$\begin{array}{l}\text { Standerdied Classification } \\
\text { Nollinal Thickness or } \\
\text { Dianieter (nin) }\end{array}$} & \multicolumn{6}{|c|}{ Steel Plate } & \multirow{3}{*}{$\begin{array}{l}\begin{array}{l}\text { Reinforcing } \\
\text { Bar }\end{array} \\
-\ldots \\
6\end{array}$} \\
\hline & \multicolumn{3}{|c|}{$S \$ 41$} & & \multicolumn{2}{|c|}{ HTRO } & \\
\hline & 6 & 9 & 12 & 16 & 5 & 8 & \\
\hline $\begin{array}{l}\text { Actual Thickness or } \\
\text { Oiameter (nim) }\end{array}$ & 5.7 & 9.0 & 11.6 & 15.6 & 5.7 & 8.4 & 5.5 \\
\hline Yield Strength $\left(\mathrm{tan} / \mathrm{cm}^{2}\right)$ & 3.27 & 2.97 & 2.90 & 2.64 & 7.14 & 7.10 & 4.01 \\
\hline Tensil Strength (ton $\left./ \mathrm{Cm}^{\circ}\right)$ & 4.39 & 4.25 & 4.24 & 4.45 & 7.91 & 7.78 & 5.11 \\
\hline $\begin{array}{l}\text { Strain at the Onsec of } \\
\text { Stain Hardening () }\end{array}$ & 2.5 & 2.0 & 2.3 & 2.0 & 1.7 & 1.8 & 1.3 \\
\hline Elongation () & 23.3 & 38.5 & 40.8 & 44.1 & 18.1 & 24.7 & 22.1 \\
\hline $\begin{array}{l}\text { Eir ensions of Test piece } \\
\text { (ur } 2 \text { 2iol) }\end{array}$ & Ho.6 & 110.13 & No. 13 & No. 13 & Mo.7 & No. 7 & No. 2 \\
\hline
\end{tabular}

Table 11 Mechanical Properties of Concrete in Joint-Panel-Shear Test Specimens

\begin{tabular}{|c|c|c|}
\hline Age (days) & 19 & 29 \\
\hline $\begin{array}{l}\text { Compressive strength } \\
\qquad \mathrm{FC}\left(\mathrm{kg} / \mathrm{cm}^{2}\right)\end{array}$ & 228 & 249 \\
\hline $\begin{array}{l}\text { Splitting Tensile } \\
\text { Strength ( } \mathrm{kg} / \mathrm{Cm} ? \text { ? }\end{array}$ & 21 & 19 \\
\hline $\begin{array}{l}\mathrm{Fc} / 3 \text { Secant Modulus } \\
\left(10^{\circ} \mathrm{kg} / \mathrm{Cr}:\right)\end{array}$ & 2.0 & 1.9 \\
\hline $\begin{array}{l}\text { Strain at the Maximum } \\
\text { Stress ( ) }\end{array}$ & 0.24 & 0.26 \\
\hline Date of Placiny & \multicolumn{2}{|c|}{ October 18,1982} \\
\hline$w / c()$ & \multicolumn{2}{|c|}{52} \\
\hline Slump $(\mathrm{cm})$ & \multicolumn{2}{|c|}{$3 n$} \\
\hline \multicolumn{3}{|c|}{$\begin{array}{l}\text { Wiameter and Height of cylinder: } 10 \mathrm{~cm} \times 20 \mathrm{~cm} \\
\text { Curinn: in air } \\
\text { liaximum size of Coarse Anvregate: } 15\end{array}$} \\
\hline
\end{tabular}




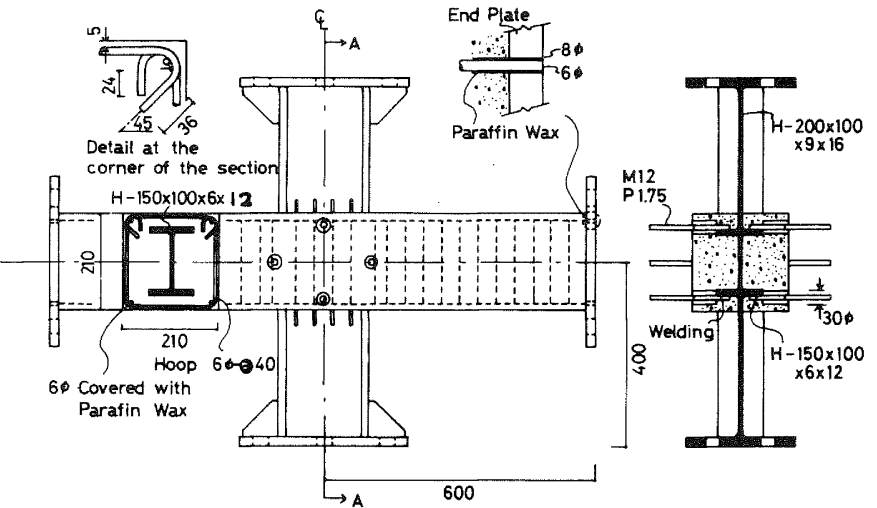

Fig 43 Dimensions of Specimen SS41-040-JPS-00

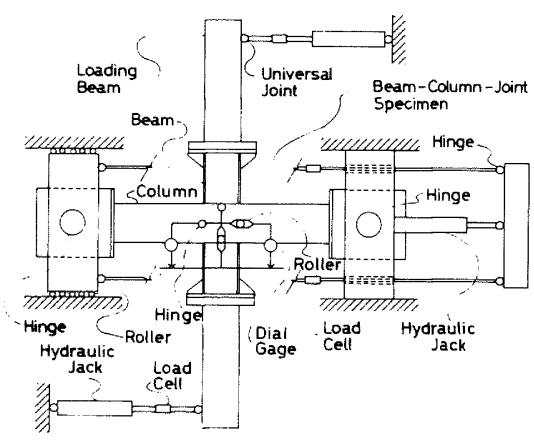

Fig 45 Loading and Measuring System of JPS Series

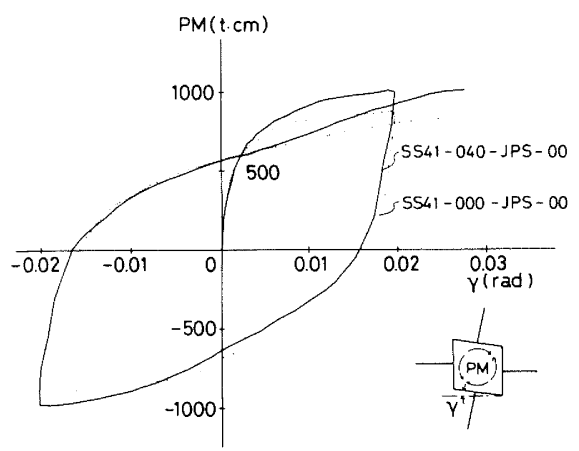

Fig $47 \quad \mathrm{PM}-\gamma$ Hysteresis of SS41 Series

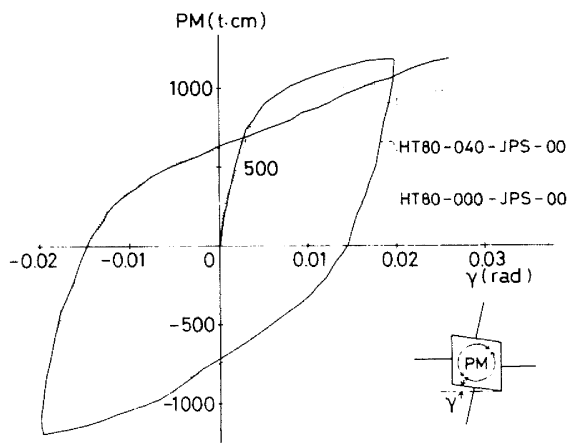

Fig 49 PM- $\gamma$ Hysteresis of HT80 Series

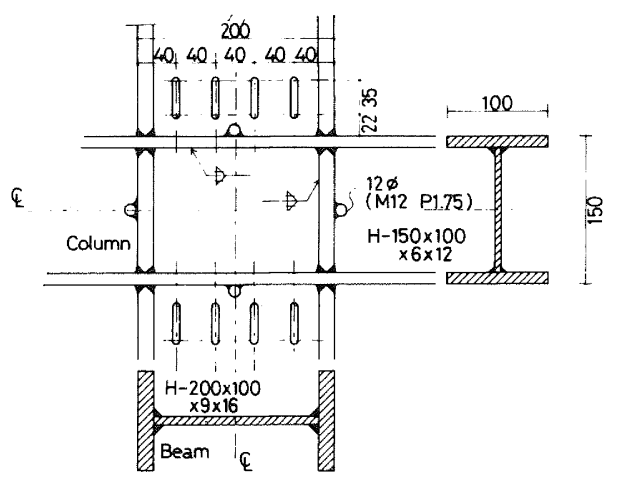

Fig 44 Detail of Specimen SS41-040-JPS-00

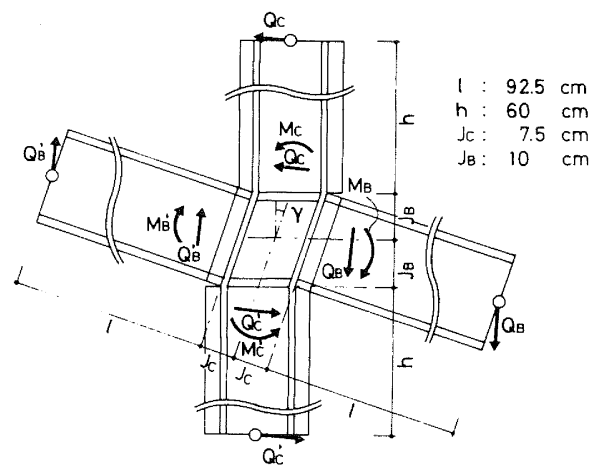

Fig 46 Forces around Joint Panel

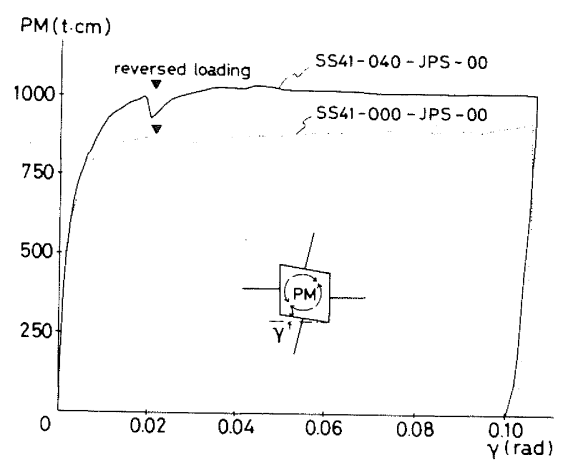

Fig 48 PM- $\gamma$ Skeleton of SS41 Series

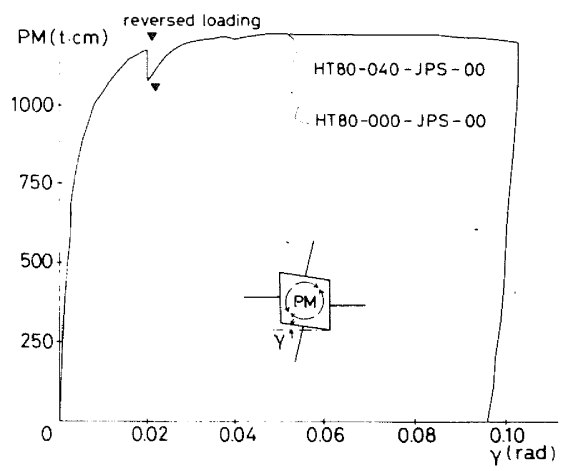

Fig $50 \quad P M-\gamma$ Skeleton of HT80 Series 
of specimens after testing are shown in photos 9 and 10 .

Failure patterns of the specimens were affected by hoop reinforcement, but were not affected much by the type of the $\mathrm{H}$ shaped steel. In the unhooped specimens, a single large diagonal crack passed through the joint and columns at gamma $=0.02 r a d$ connecting both column end plates. At the maximum deformation gamma $=0.1 \mathrm{rad}$, the joint panel concrete outside the stiffners and flanges of the column spalled almost completely. Only the concrete enclosed within the stiffners and flanges remained in the joint panel. Spalling occurred in the connecting columns as well. On the other hand, the concrete in hooped specimens was well confined. At gamma $=0.02 \mathrm{rad}$, a lot of inclined narrow cracks were observed in the joint panel but they did not penetrate the column. At gamma $=0.1 \mathrm{rad}$, half of the cover concrete spalled but the core concrete within the hoop did not spall.

The joint panel strengths were affected by hoop reinforcement. The strengths of hooped specimens at gamma $=0.02 \mathrm{rad}$ were about 14 percent higher than those of unhooped specimens, irrespective of the type of $\mathrm{H}$-shaped steel. The ductility, however, was not affected by hoop reinforcement. The strengths of the unhooped SS41 and HT80 specimens at gamma $=0.1$ rad were 7 percent and 4 percent higher than those at gamma $=0.02 \mathrm{rad}$ respectively.

The panel moment carried by the steel web PMs can be estimated as PMs = Vs*fs, where $V s=t w * J b * J c, t w$ is measured web thickness, and fs is maximum tensile strength of steel divided by root 3. This equation yields PMs $=853 t^{*} \mathrm{~cm}$ for $\mathrm{SS} 41$ and $781 \mathrm{t}^{\star} \mathrm{cm}$ for HT80. These values are considerably less than the strengths of both the unhooped and hooped specimens. This indicates that the concrete of the unhooped specimens enclosed within the steel contributed to the strength of the joint panel even at large deformations.

The loading of this test series was conducted without axial force. Further experiments should be conducted with axial force.

\section{CONCLUSION}

1. The proposed SRC system - "H-shaped high strength $\left(80 \mathrm{~kg} / \mathrm{mm}^{2}\right)$ steel' "concrete", "hoop reinforcement" composite - has quite good aseismic performance.

2. Flexural cracks concentrated at the critical sections in the proposed SRC members subjected to bending-shear, and flexural-shear cracks were not observed.

3. Hoop reinforcement improved the compressive behaviour of the concrete and protected the steel from local buckling.

4. Hoop reinforcement contributed to the strengths of the proposed SRC members subjected to bending-shear, but little to those of normal strength steel.

5. Hoop reinforcement contributed to the joint panel shear strengths of SRC with either high strength or normal strength steel.

6. Hoop reinforcement contributed to the ductility of members under various loading conditions. As for the joint panel shear, unhooped specimens as well as hooped specimens showed large ductility.

7. One defect of the proposed SRC member subjected to bending-shear is that the tensile fracture of the steel flange is more liable to occur than that of normal strength steel. This is attributable to the inelastic strain concentration, and shall be surmounted by some devices such as the tapering of the steel flange.

8. Deformation of the SRC member under compression is due not only to compressive strain but also to slip along the inclined crack, and affected by the existence of the $\mathrm{H}$-shaped steel itself. The relationship between compressive force and deformation of SRC cannot be evaluated as the sum of those components of concrete and steel.

9. The maximum moment carried at the critical sections of members under bending shear were greater than those under bending. Compressive stress-strain relationship of concrete in the members under bending-shear should be affected by the restraint of the neigh bouring solid concrete.

\section{ACKNOWLEDGEMENT}

Grateful thanks are due to various useful suggestions by Dr Tsukasa Aoyagi, Nikken Sekkei co Ltd, during the preparation of this study. The help of Mr Masahiro Kato, Sumitomo Metal Industries Ltd, is also appreciated.

\section{REFERENCES}

1. Takiguchi K. "Deforming Characteristics of $\mathrm{R} / \mathrm{C}$ Members with and without Bond. II". Transcript of Architectural Institute of Japan, No 262, December 1977, pp 5360 (in Japanese).

2. Park R, Priestley $M J N$ and Gill $W$ D. "Ductility of Square Confined Reinforced Concrete Columns." Proceedings, ASCE, Vol 108, No ST4, April 1982, pp 929-950.

3. Sheikh S A and Uzumeri S M. "Properties of Concrete Confined by Rectangular Ties." AICAP-CEB Symposium on Structurai Concrete Under Seismic Actions (Rome, May 1979). Bulletin d'Information No 132, Comm Euro-International de Beton, Paris, 1979, pp $53-60$. 
Appendix

- Experimental Results of R/C Beams with and without Bond -

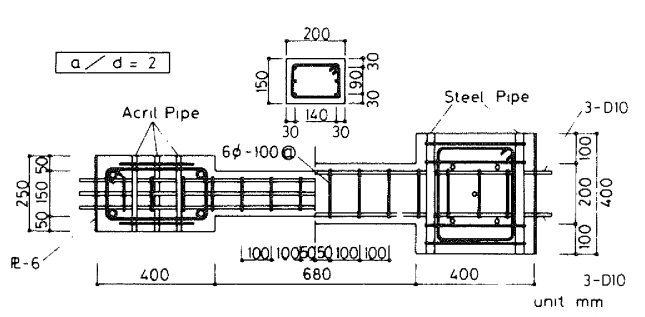

Fig A-1 Specimens
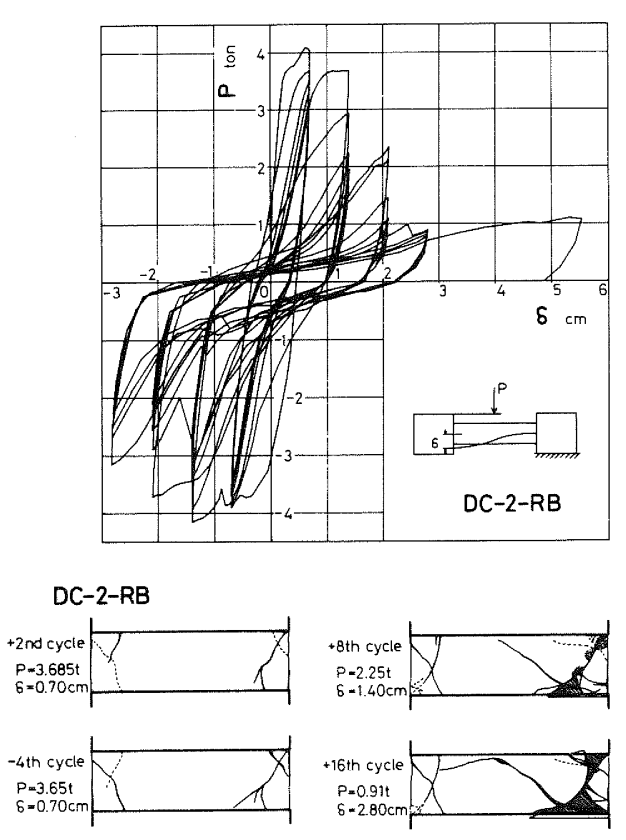

Fig A-3 P- $\delta$ Curves and Cracks

- with Bond -

- Cyclic Loading -

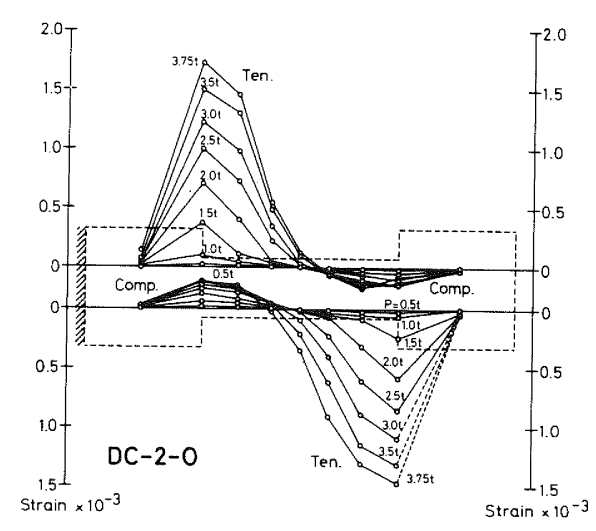

Fig A-5 Strain

- with Bond -

- Monotonic Loading -

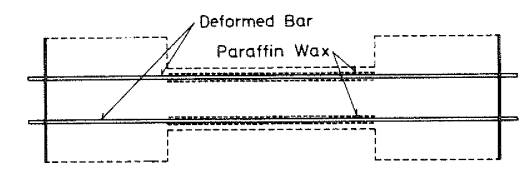

Fig A-2 Londitudinal Reinforcements of the Specimens without Bond
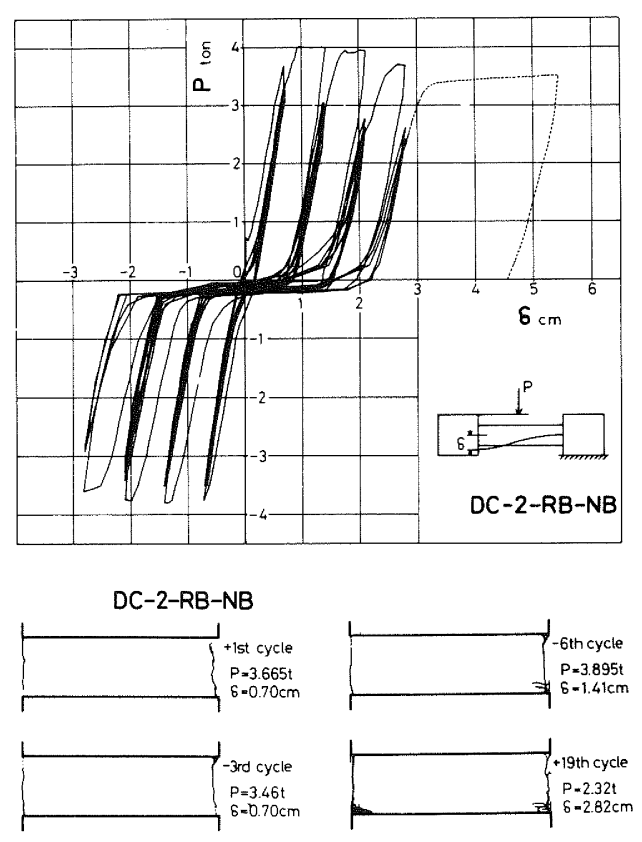

Fig A-4 P- $\delta$ Curves and Cracks - without Bond -

- Cyclic Loading -

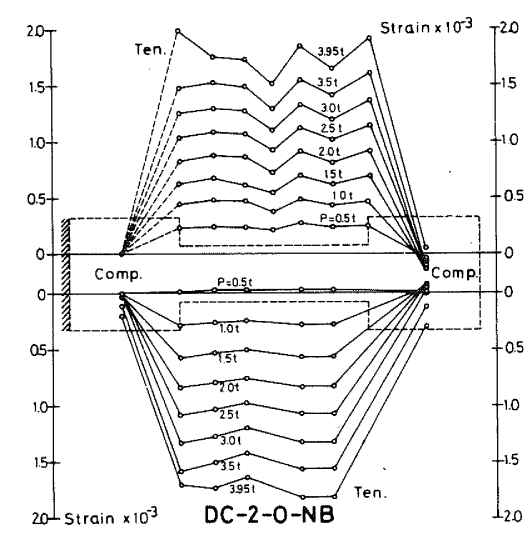

Fig A-6 Strain

- without Bond -

- Monotonic Loading - 